The role of Demographics and Psychographics in the relationship ......

Omnia Abdelazeem abdelhaleem Hilal

\title{
The role of Demographics and Psychographics in the relationship between social media Marketing and Brand awareness among smartphone users in Egypt
}

\author{
Omnia Abdelazeem abdelhaleem Hilal \\ Assistant lecturer, Faculty of Commerce \\ Zagazig university \\ Omnia_hilal@zu.edu.eg
}

لقد نمى في الفترة الأخيرة استخدام مواقع التواصل الاجتماعي بشكل متز ايد

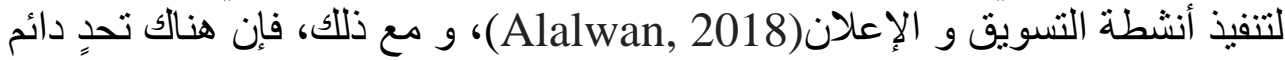
في كيفية الاستفادة من مواقع التواصل الاجتماعي في التسويق و و استخداماتها

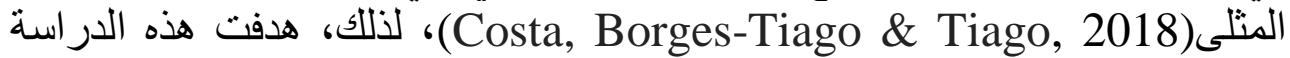

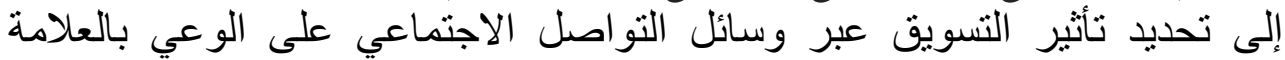

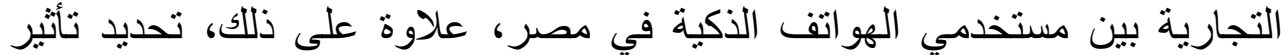

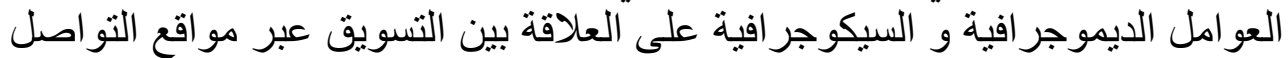

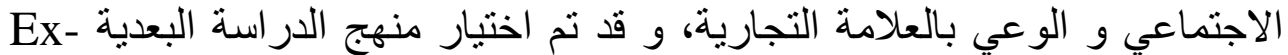
post facto

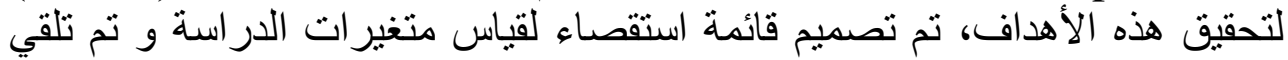

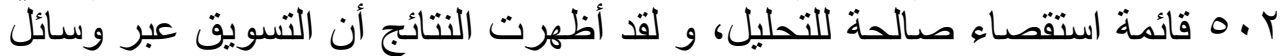

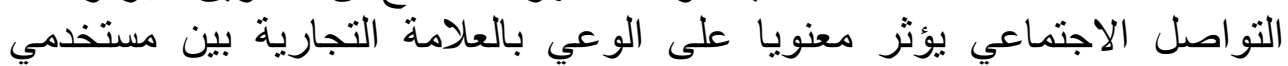

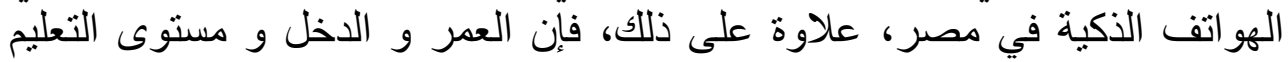

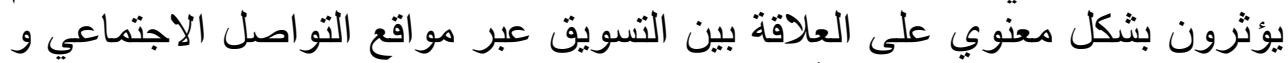

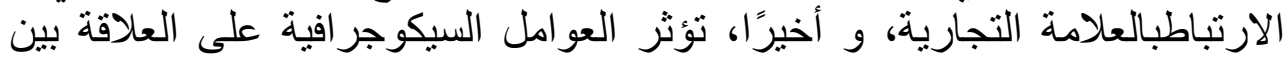

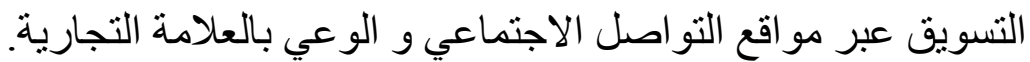

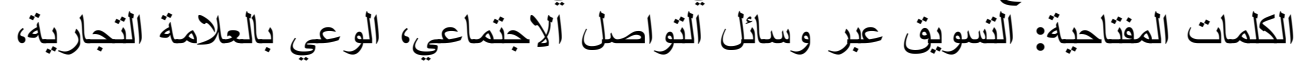

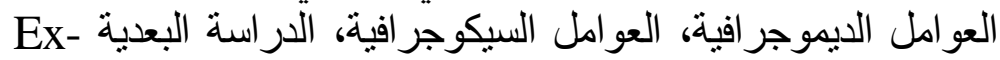

\section{Abstract:}

.post facto

Social media are increasingly finding a place for themselves in all aspects of our lives. Social media are being extensively used as a platform to conduct marketing and advertising activities 
The role of Demographics and Psychographics in the relationship ......

Omnia Abdelazeem abdelhaleem Hilal

(Alalwan, 2018). However, there is always a challenge in how organizations can figure out the results of social media marketing (Costa, Borges-Tiago \& Tiago, 2018). Therefore, this study aimedto determine the effect of social media marketing on brand awareness among smartphone users in Egypt, moreover, to identify the effect of demographics and psychographics on this relationship. Ex-post facto design has been chosen to achieve the research objectives. A questionnaire has been designed and a cluster sample consisting of 502 smartphone users have been surveyed. Results showed that social media marketing significantly affects brand awareness, moreover, smartphone users' age, income, and education significantly affect this relationship. Finally, smartphone users' psychographics significantly affected this relationship.

Keyword: Social Media Marketing, Brand Awareness, Demographics, Psychographics, Smartphones, ex-post facto design.

\section{1/ Introduction:}

In less than two decades, social networking has become a global phenomenon that is attractive to both individuals and corporations (Ouoba, 2011). Indeed, 3.196 billion are on social media out of 4.021 billion on internet (Annual Digital Report, 2018), therefor, countless consumers and potential consumers can be reached through various digital channels: emails, social networking sites, blogs and micro-blogs, peer review or referral sites, and social content sites. Hence, more companies are encouraged to use social media as more people are joining social network sites which offer simple and inexpensive means to market brands and communicate customers.

Many organizations use social media to promote their products, as well as simply share information (Golijan, 2011) as it is an ideal form of communication to reach a large audience as well as specific targeted audience that do not require any financial resources (Pring, 2012). Social media brings an 
The role of Demographics and Psychographics in the relationship ......

Omnia Abdelazeem abdelhaleem Hilal

interesting dynamic to the sales and marketing interface at which customers want to voice their concerns, and want to be educated on products and services as a move from passive to active presence, (Liu, 2012; Marshall et al., 2013).

Future consumer marketing will largely be carried out in digital settings, particularly social media (Stephen, 2016). With the increased use of social media marketing by several types of brands, it has become highly necessary to quantitatively analyze this phenomenon. Thus, studying the consequences of social media marketing is the main purpose of this research targeting to spot more light on this new technological marketing communication strategy through investigating the effect of social media marketing on brand awareness.

Smartphones have become an inseparable part of our daily lives. Nowadays, smartphones and social media go hand in hand as $92.5 \%$ of global browsing social media is through smartphones (Annual Digital Report, 2018). In recent years, mobile devices have taken social media marketing to a whole new level as users continually choose to access their networks remotely, via smartphones, tablets, and laptops.

Therefore, studying the effect of social media marketing on brand awareness among smartphone users in Egypt will enhance marketers' understanding and knowledge about consequences of social media marketing and factors affecting this relationship.

\section{2/ Literature review and hypothesis development:}

In the new age of information superhighway and new technologies, the old way of branding and marketing a product is unconventional and outdated (Alkhas, 2011). Traditional, nontargeted advertising via newspapers, magazines, radio, television, and direct mail were the only means of marketing a product where the messages are product focused- one way while they are now required to compete with new marketing strategies on the Web that is centered on interaction, information, education, and choice (Scott, 2007). The Web marketing is different, instead of 
The role of Demographics and Psychographics in the relationship ......

Omnia Abdelazeem abdelhaleem Hilal

one-way interruption; it is about delivering useful content at just the precise moment that a buyer needs it. The feedback from customers has also become vital for businesses because customers are not able to share opinions on the web where other customers can also see this feedback (Alkhas, 2011).

Social media users are involved together in sharing, linking, collaborating, and producing online content using text, photo, audio, and video (Ioakimidis, 2010). Social networks also provide opportunities to marketers including the ability to listen to fans, respond to them, discuss issues, reach common understandings, and in due course, strengthen long-term relationships (Williams \& Chinn, 2010). The more an organization or brand has publics talking about how great they are, or trustworthy, or responsible, or insightful, the more the general public may perceive them as credible. These online conversations are called electric-word-of-mouth and are one of the strengths of social media marketing.

Social media marketing (SMM) has been defined as "a philosophy and a business strategy, supported by a technology platform, business rules, workflow, processes and social characteristics, designed to engage the customer in a collaborative conversation in order to provide mutually beneficial value in a trusted and transparent business environment" (Evans, 2010). This definition highlighted that SMM has different characteristics from traditional marketing, which ranging from establishment of communication with potential and current consumers, user generated classification, interactivity with consumers; to the opportunity for consumers to take control of the content of information, communication or other related activities about a brand (Garnyte \& De Ávila Pérez, 2009).

Empirical research regarding the specific use of social network sites has described user personalities and motivations for use (Ross et al., 2009); dimensions of uses and gratifications (Bonds-Raacke and Raacke, 2010); and consumers' response to 
The role of Demographics and Psychographics in the relationship ......

Omnia Abdelazeem abdelhaleem Hilal

branded communication on the sites in terms of advertiser credibility (Lee, Kim, \& Chan-Olmsted, 2011), involvement (Muntinga, Moorman, Smit, 2011) and effectiveness (Calder, Malthouse \& Schaedel, 2009).

Previous studies concerning SMM aimed at assessing its usage and effectiveness (Marzouk, 2016; Ouoba, 2011), strategies (Chanthinok, Ussahawanitichakit, \& Jhundra-indra, 2015; Karimi and Naghibi, 2015; Lorenzo-Romero, Constantinides, Alarcón-del-Amo, 2013; Gordon, 2017), barriers and measurement (Michaelidou, Siamagka, Christodoulides, 2011), public opinion formulation (Gazzar, 2013), considerations and implications (Botha, 2014), opportunities and challenges (Abeza, 2012), cultural, ethical and legal considerations (Amin, Qureshi, Chandio, 2017), antecedents and consequences (Somali, 2018), and adoption models and stages (TsitsiChikandiwa, Contogiannis, \&Jembere, 2013). Another stream of studies focused on understanding how social media marketing impacts marketing-related outcomes, such as consumers' purchase intentions (Wang, Yu, and Wei, 2012; Hutter et al, 2013), brand perceptions (Naylor, Lamberton, and West, 2012), the selling environment (Marshall et al., 2012), company ROI (Fisher, 2009; Hoffman and Fodor, 2010), customer equity (Kim and Ko, 2012), brand awareness (Hutter et al, 2013), and brand equity creation (Bruhn, Schoenmueller, Schäfer; 2012). Finally, social media marketing effect on business growth (Aloch, 2017) has been studied.

Although social media marketing is considered a new rapidly growing platform for building relationships with customers and forming positive image of brands in their minds, its impact on number of psychological and behavioral consequences is still missed. Brand awareness is a brand aspect that has attracted scholars' and practitioners' attention in the last few years. Nevertheless, how SMM can result in enhancing this

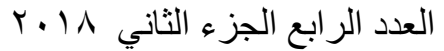

المجلد التناسع 
The role of Demographics and Psychographics in the relationship ......

Omnia Abdelazeem abdelhaleem Hilal

aspect, in other words, SMM consequence in the terms of brand awareness is yet to be understood.

Brand awareness is related to the ability of the consumer to identify the brand under certain conditions. The greater the awareness is, the better work that each of the brand identities (logo, name, characters, design, slogan or any symbols) has done (Keller, 1993). There are two possibilities of how brand awareness can be expressed. One is through brand recall or the process when a certain brand is recalled by the consumer when he is given a certain category as a cue, and brand recognition when respectively a consumer is able to recognize the brand when he is given a brand as a prompt (Dew \& Kwon, 2009). Scholars claim that brand recognition may be more important than brand recall as most of the decisions people made are made in the store and rarely outside of it (Keller, 1993).

According to the associative model theory by Anderson (1983), awareness is a crucial and preliminary step for the formation of brand associations. This statement is also confirmed by the theory of Keller, (2013) for the building blocks of customer-based brand equity, where he puts awareness as the most important factor needed for the realization of the other ones. Once the customer attaches associations to the brand then some feelings and judgments will follow, which by themselves represent the brand attitude (Keller, 2013).

In the recent years people got significantly engaged in social media platforms. That's why companies started using namely social media for creating awareness as it has been proved that social media marketing increases brand awareness (Hutter et al, 2013; Barwise \& Meehan, 2010; Barreda et al, 2015; Keller, 2009; Swani et al, 2013; Malhotra, Malhotra, See, 2013; Muñiz, \& Schau, 2011; and Thoring, 2011, Ntobaki, 2018).

Although there is a stream of studies confirmed that there is a positive relationship between SMM and brand awareness, there is sufficient number of researches confirming that there is 
The role of Demographics and Psychographics in the relationship ......

Omnia Abdelazeem abdelhaleem Hilal

no relationship between them (Hames, 2009; La Pointe, P., 2012; Bruhn, Schoenmueller, \& Schäfer, 2012). This contradiction highlights a scientific gap which requires more research and investigation about the effect of social media marketing on brand awareness and leads to the formulation of the following hypothesis:

\section{Hypothesis 1: Social media marketing significantly affects brand awareness among smartphone users in Egypt.}

Demographics provide descriptive information about who product buyers are. Businesses owners need demographics to identify the ideal consumer for products or services and develop marketing strategies such as product packaging, advertisements, business location and pricing. Hustad \& Pessemier (1971) suggested that the value of demographic information is primarily in identifying whether a consumer has a basic need for a product and whether he is capable of purchasing it.

Demographic characteristics provide a relatively straightforward and reliable basis for segmentation (Assael, 2004; Engel, Blackwell \& Miniard, 2006; Koufaris, 2002; Straughan \& Roberts, 1999), moreover, it has been shown to play a significant role in determining the behavior of individuals and web users (Girard et al., 2003; Korgaonkar \& Wolin, 1999). Based on the previous argument, in the context of our study, demographic variables will be examined to determine if they affect the relationship between social media marketing and brand awareness among smartphone users in Egypt. Therefore, the following hypotheses were formulated.

Hypothesis 2: Consumers' gender affects the relationship between social media marketing and brand awareness among smartphone users in Egypt

Hypothesis 3: Consumers' age affects the relationship between social media marketing and brand awareness among smartphone users in Egypt

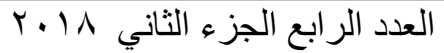
المجلد التاسع 
The role of Demographics and Psychographics in the relationship ......

Omnia Abdelazeem abdelhaleem Hilal

Hypothesis 4: Consumers' marital status affects the relationship between social media marketing and

brand awareness among smartphone users in Egypt

Hypothesis 5: Consumers' income affects the relationship

between social media marketing and brand awareness

among smartphone users in Egypt

Hypothesis 6: Consumers' education affects the relationship

between social media marketing and brand awareness among smartphone users in Egypt

Hypothesis 7: Consumers' occupation affects the relationship

between social media marketing and brand awareness among smartphone users in Egypt.

Demographic variables alone are generally not "powerful" predictors of individual or household behavior in the marketplace (Bieda and Kassarjian, 1971). The limitation of studying demographics aloneleaded to the development of psychographics. The new construct, psychographics -or commonly known as lifestyle- combines the virtues of demographics with the richness and dimensionality of psychological characteristics and depth research.

Psychographics are factors that contribute to explaining consumer behavior (Myrland et al. 2000; Olsen et al. 2007; Pieniak et al. 2008; Bruns $\varnothing$ et al. 2009). They represent the internal influences that affect the consumer's decision-making process and consists of aspects about consumer's personality, buying motives, interests, attitudes, beliefs and values.

According to Engel, Blackwell \& Miniard (1990) psychographics are used to develop an in-depth understanding of market segments and therefore used for developing marketing strategies for brands. The purpose of the analysis is to "understand consumer lifestyles of the core consumers in order to communicate more effectively with people in that segment. However, knowledge about the role psychographics play in SMM usage is still missed. In addition, businesses get consumers' 
The role of Demographics and Psychographics in the relationship ......

Omnia Abdelazeem abdelhaleem Hilal

demographic, geographic, psychographic information from their social media profiles and target ads individually tailored to consumer (Hoy \& Milne, 2010).

In conclusion, psychographics play an important role in consumer decision making process, can affect consumer perception of different marketing aspects, and examining psychographic constructs is extremely important in marketing research (Gironda, 2014), but how could they mediate the relationship between SMM and its possible outcomes is yet uncovered. This argument leads to formulation of the following hypothesis:

Hypothesis 8: Consumers' psychographics affect the relationship between social media marketing and brand awareness among smartphone users in Egypt.

\section{3/ Research problem:}

Social media marketing is increasingly replacing traditional media marketing, and the buzz about these new marketing opportunities seems unlimited. So many facts can explain why social media is the mainstay of communication between business-to-business and business to consumer endeavors:

- In 2013, engaging through social media became the number one single online activity for individuals (Smith, 2013). More time is spent in social media than on entertainment and shopping combined, the next two largest time-consuming online activities (Experian, 2013).

- Studies showed that $15 \%$ of time spent on these devices is in social media (Experian, 2013). Additionally, mobile access has increased by over $60 \%$ within two years and older demographics, which some once discounted as individuals who would never adopt social media, have become some of the fastest growing populations on platforms such as Twitter, Facebook and Google+ (Bullas, 2013). 
The role of Demographics and Psychographics in the relationship ......

Omnia Abdelazeem abdelhaleem Hilal

- It took television 13 years to reach 50 million households and internet service providers three years to sign their 50 millionth subscribers. However, it only took Facebook one year to attract 50 million users and Twitter only nine months (Chui et al., 2012).

- By the end of 2012, approximately $67 \%$ of all online adults with an online presence used social media sites. Facebook is now the largest social media site in the world, currently hosting over 1.2 billion users-a number that continues to grow. Each day, Facebook processes 2.7 billion "Likes," 300 million photos uploads, and 2.5 billion status updates and check-ins (Vance, 2012).

- Over $90 \%$ of people reportedly search for local businesses through Facebook and $71 \%$ are more likely to purchase from a brand they follow online (Bennett, 2013). Social media sites accounted for 22 per cent of online advertising spending during 2011 and nearly 60 per cent of US marketers and ad agencies planned to increase their spending on social media sites during 2012 (Advertiser Perceptions, 2012).

Although the use of social media sites such as Facebook and twitter by organizational leaders as a marketing communication tool is becoming increasingly a popular tactic (Piskorski, 2011), a significant lack of knowledge persists with respect to social media marketing effectiveness, success and failure factor, possible outcomes. Moreover, some companies are reluctant to join social media sites (Grant Thornton LLP, 2010; Best, 2011) as it is not certain how effective these social marketing and communication efforts are on consumers' preferences. Marketers and business owners have shifted resources, both capital and human, from traditional marketing modalities to the use of social media without knowledge of its consequences (Bulearca \& Bulearca, 2010).

In fact, the companies that have a social network page used to communicate with current and possible customers know the 
The role of Demographics and Psychographics in the relationship ......

Omnia Abdelazeem abdelhaleem Hilal

number of persons who follow them and like their brand(s) or product(s). However, the companies are not able to determine how many of the people who "Like" their products actually purchase them as a result of the online interactions they have with the source. So many questions arise: Does the presence of companies on social networking sites have a real impact on consumers? Do social networking site users actually purchase a product from a company because of the awareness they had from these sites with the company?

The research problem can be stated in the following questions;

- Does the use of SMM as a communication tool enhance brand awareness?

- Do demographics and psychographics affect the relationship between SMM and brand awareness?

Providing insight to this issue will help those making marketing decisions better understand the effects that having for example a Facebook brand page or a twitter brand platform might have on brand awareness, and the role of demographics and psychographics play in these relationships.

\section{4/ Research Objectives:}

The main objective of this study is to fill the research gap by developing a model for the effect of social media marketing on brand awareness and what are the factors affecting these relationships. The main objective can be achieved through achieving the following sub objectives:

- Determining the effect of social media marketing on brand awareness among smartphone users in Egypt.

- Determining the role of demographics and psychographics in the relationship between social media marketing and brand awareness among smartphone users in Egypt.

Figure (1) shows the research proposed model and hypotheses. 


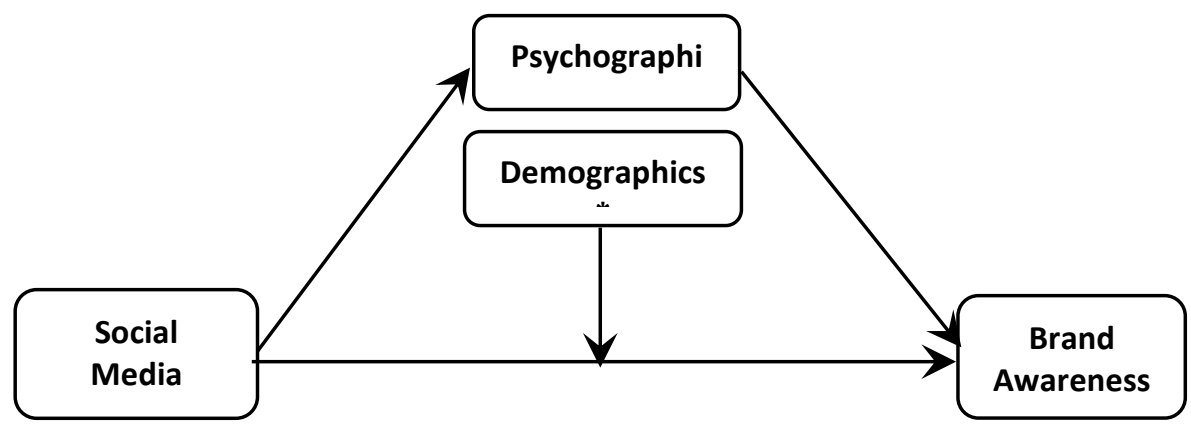

Figure (1): Research proposed model and hypothesized relationships.

* Gender, age, marital status, income, education, and occupation.

As shown in the figure, demographics role will be tested through moderation analysis as they are not affected by the independent variable (due to its nature; nothing affects gender, age, education, etc.). The role of psychographics will be tested through mediation analysis as they are first affected by the independent variable (consumers' lifestyle can be affected by several factors including social media and social media marketing) then is supposed to affect the dependent variable.

\section{5/ Research importance:}

Many researchers disputed that social media have several benefits as they allow the creation and exchange of usergenerated content (Kaplan and Haenlein, 2010), and represent a rich context for awareness manifestations, as they foster the creation of strong, interactive consumer relationships (Gummerus et al., 2012), while they permit the proliferation of online consumption and brand communities rich in consumer participation (Zaglia, 2013).

With the modification of social communication brought about by social network sites, companies must adopt and keep on developing strategies that allow them to be closer to the audience they target. Companies have no other option than positioning 
The role of Demographics and Psychographics in the relationship ......

Omnia Abdelazeem abdelhaleem Hilal

themselves where their audience is. A Grant Thornton LLP study (2010) reported, "Social media is rapidly becoming 'a must' for business success". As a result, more companies have joined social network without a clear evidence of how this presence may affect brand awareness.

Study results should be valuable from a practical/applied perspective as well. Findings of this study should provide a basic understanding of the direct effect of social media marketing on brand awareness among smartphone users in Egypt. Answers to research questions will provide valuable information and guidance for marketing planning and action concerning the necessity of business social media presence and its direct outcomes. Moreover, the moderating/mediating role of demographics and psychographics is believed to be useful as managers and marketers of smartphones in Egypt will be able to design marketing plans to communicate effectively with their potential and current target markets and enhance brand awareness. Professional smartphones marketers and advertisers will be able to rely less on high expensive traditional media, make more rational decisions with regard to their promotional budgets, and target their marketing communications mix more effectively.

\section{6/ Methodology:}

Toexamine the research hypotheses, thecurrent study adopted a quantitative method. The following methodology has been chosen to achieve the research objectives.

\section{6/1/The research design and method:}

In order to achieve the research objectives and answer its questions, the causal research design has been used as it is one of the best research designs that enables exploring the cause-effect relationship through executing experiment (Sekaran \& Bougie, 2016).

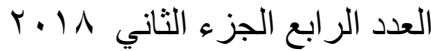

المجلد التاسع 
The role of Demographics and Psychographics in the relationship ......

Omnia Abdelazeem abdelhaleem Hilal

As this study aims at investigating the effect of social media marketing on brand awareness, and there is a group of consumers already have been exposed to social media marketing and depending on the brand page on social media (specifically Facebook) to know about the brand marketing efforts, while there is another group of consumers have not been exposed to social media marketing and still depending on traditional media (TV, magazines, ad boards,.. etc.) to learn about the brand marketing efforts, ex post facto design (as one of the quasiexperiment designs) would be the suitable experiment setting. Brand awareness might now be measured for both groups to identify the effect of social media marketing.

\section{6/2/Population:}

A study conducted by AppMaker showed that Egypt occupied the first rank in Africa as the highest prevalence of mobile phones in 2014 with $68.7 \%$ smart phones use. Smartphones (opposite to feature phones) and tablets were the most frequently used devices when accessing the web compared to laptops and desktops. Handheld devices like smartphones and tablets became versatile while also became accessible for most people (Solangaarachchi et al, 2016). A new report issued by Zenith, a unit of the French ad agency, predicted that $75 \%$ of the use of the Internet by 2017 is via mobile, a slight increase from the current year, as the growing number of consumers around the world has access to the World Wide Web via smartphones and tablets.

According to the Arab social media report (2015), smartphonesare the main mode of access to social media. The majority of respondents $(83 \%)$ access or use social media via their smartphones most of the time, compared to $11 \%$ who use their laptops. The majority (84\%) of social media users in Arab World visit Facebook through their smartphones and/ or tablets.

To answer the research questions and achieve its objectives, smartphone users have been chosen as a population 
The role of Demographics and Psychographics in the relationship ......

Omnia Abdelazeem abdelhaleem Hilal

because smartphones users are not only brand page followers, rather, some of them are traditional marketing followers. Therefore, smartphone users are suitable as population for the purposes and hypotheses of the current study as they consist of consumers that prefer to know about brands through social media and consumers that prefer to know about brands through traditional media.

Social media sites are numerous including Facebook, twitter, instgram, YouTube, LinkedIn, whatsapp..etc,. According to Arab social media report (2015), Facebook and WhatsApp are the most used social media channels across the Arab world, while Facebook was the top used social media channel on the aggregate level of the Arab World. This study will be limited to studying the effect of Facebook marketing as representative of social media marketing on brand awareness.

\section{6/3/ Sampling:}

Sampling process has been through the following steps:

\section{6/3/1/ Sample size and type:}

Krejcie and Morgan (1970) greatly simplified size decision by providing a table that ensures a good decision model and provides that generalized scientific guideline for sample size decisions. As long as the population size (smartphone users in Egypt) is approximately 65million and based on the table, a sample of size 600 respondents is suitable depending on $4 \%$ confidence level.

As this research aims at exploring a specific phenomenon within population units through surveying sample units, it is good to use probability sample. Since the researcher desires to use probability sample, there is no population frame, and there are survey maps, it is ideal to use cluster or area samples (Sekaran \& Bougie, 2016).

\section{6/3/2/ Choosing sample units:}

Cluster sampling have been done in several stages (multistage cluster sampling) to collect data with maximum 
The role of Demographics and Psychographics in the relationship ......

Omnia Abdelazeem abdelhaleem Hilal

accuracy and minimum cost and cover all population units which are widespread all over the nation. Table (1) shows how sample units have been chosen.

First, Egypt governorates are divided into seven regions;

1- Cairo region: Cairo, Kaliobia, and Giza .

2- Alexandria region: Alexandria, Matrouh, Behera.

3- Sues Canal region: North Sinai, South Sinai, Port Said, Sharkeya, Ismailia, and Suez, .

4- Nile Delta region: Monofia, Gharbeia, Dakahlia, Damietta, and KafrElshiekh.

5- North Upper Egypt: Beni Suif, Fayoum, and Menia

6- Middle Upper Egypt: Asiout, New valley.

7- South Upper Egypt: Kena, Sohag, Aswan, Luxor, and Red Sea.

Second: The researcher randomly drew 7 governorates (more than $25 \%$ of the governorates) out of the 27 governorates.

Third: the random selection of the governorates has resulted in choosing Cairo, Behera, Asiout, Sohag, Menia, dakahlia, and Sharkeya.

Table (1): Sample units' distribution on selected governorates

\begin{tabular}{|l|c|c|c|}
\hline Governorate & Population* & $\begin{array}{c}\text { \% of total } \\
\text { population }\end{array}$ & Sample units \\
\hline Cairo & $9,595,813$ & 22 & 132 \\
\hline Behera & $6,102,422$ & 14 & 84 \\
\hline Sharkeya & $6,790,797$ & 16 & 93 \\
\hline Dakahlia & $6,191,160$ & 14 & 85 \\
\hline Asiout & $4,481,735$ & 10 & 61 \\
\hline Sohag & $4,862,308$ & 11 & 67 \\
\hline Menia & $5,459,795$ & 12 & 75 \\
\hline Total & $43,484,030$ & 100 & 600 \\
\hline
\end{tabular}

* Data obtained from the annual book (2017) of the Egyptian 
The role of Demographics and Psychographics in the relationship ......

Omnia Abdelazeem abdelhaleem Hilal

Central Agency for Public Mobilization and Statistics.

It is shown that all Egypt governorates regions are represented in the sample, where every region is represented by one governorate. The selected governorates population represents more than $39 \%$ of total Egypt population. Sample units for each government have been determined according to proportional distribution.

\section{6/3/3/ Sample Units:}

Sample units are Egyptian smartphone users whether following a brand Facebook page or not. The researcher has tried to survey consumersabove 18 years old who are using smartphone for at least six months and for consumers who depend on social media marketing, they should have been doing that for at least three months.

As there is no population frame, the researcher has set up several arrangements to ensure the core of randomization (Edrees, 1996); that is data collection from sample units in front of smartphones customer service centers has been done considering the following:

- Random selection of the customer service centers to reduce location bias.

- Intercepting one smartphone user every 20 minutes.

- Intercepting smartphone users during all days of the week to reduce time bias.

- Intercepting smartphone users in several times during day and night of the day to reduce time bias.

- Introducing the researcher herself, introducing title, and some of the objectives of the research.

- Giving respondents full time needed to fill out the instrument.

\section{6/4/Variables and Operationalization:}

العدد الر ابع الجزء الثاني 11

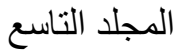


The role of Demographics and Psychographics in the relationship ......

Omnia Abdelazeem abdelhaleem Hilal

Based on research objectives, research variables are social media marketing as an independent variable, brand awareness as dependent variable, and demographics and psychographics features are moderating/mediating variables. A deeper explanation and discussion about variable and operationalization follow.

- Brand awareness: Brand awareness has been operationally defined in terms of its two dimensions, brand recognition and brand recall. Brand Awareness was early measured through 5 items (Atilgan, Aksoy, \& Akinci, 2005; Yoo, Donthu, \& Lee, 2000) which will be used with slight modification in the current study as it is the most used in previous studies.

- Social media marketing (SMM) is the independent variable. The experimental group has been previously exposed to SMM. The treatment (SMM) will be measured to make sure that the sampling unit in the experimental group has really been exposed to the treatment. SMM has been measured using several diverse scales reflecting the respondents' perception of the SMM activities by companies.

Mägi (2003) and Tsiros et al (2004) measured firm created social media communication by 3 items scale. According to Soh, Reid, and King's (2009), the perceptions of social media marketing were divided into trust and global perceptions (33 items). The trust measures were created by sixteen items construct the four sets of AD-trust composite measures. The items measured participants' perceptions of reliability, usefulness, effect of social media marketing, and willingness to rely on social media marketing. Participants' global perceptions of SMM advertising and virtual brand communities were also assessed (Cheng et al. 2009). Of specific interest were their evaluations of the extent to which social media marketing was informative, entertaining, and irritating. 
The role of Demographics and Psychographics in the relationship ......

Omnia Abdelazeem abdelhaleem Hilal

Kim \& Ko (2012) measured perceived SMM activities through several dimensions reflecting entertainment, interaction, trendiness, customization, and word of mouth. The scale was adopted from previous studies. Finally, Sheth (2013) measured SMM by three dimensions (information sharing, peer pressure, and entertainment) which were borrowed from several previous studies (Smock et al, 2011; Himberg, 1996; Peslak, 2011).

The current study will use the scale developed by Kim \& Ko (2012) as it is the most comprehensive one and has been lately validated (Yadav, Rahman, 2017).

- Demographic characteristics include age, gender, marital status, income, occupation, and education.

- Psychographics consists of three dimensions; activities; how consumers spend their times, interest; what preferences consumers have, and opinions; how consumers stand on social issues, products, or a variety of other issues. Psychographics scale (the AIO statements) adapted from Wells \& Tigert (1971), Sun, Horn \& Merritt (2004), and Swinyard \& Smith (2003) is too long consisting of 52 statements. Mitchell (1983) developed AIO scale and added the concept of value. He explained that a mixture of personal life and perceived value determines consumer behavior, while a perceived value is a synthesis of individual beliefs, attitudes, hopes, and demands. Yu (2011) operationalized e-lifestyle by employing four constructs of e-activities, e-opinions, e-interests, and evalues. This research will use the scale developed in the work of $\mathrm{Yu}$ (2011) to conceptualize e-lifestyle construct.

\section{6/5/ Questionnaire:}

The instrument development has gone through several stages starting from designing the questionnaire, validating, editing, ending with reliability test. These stages are presented below in more details. 
The role of Demographics and Psychographics in the relationship ......

Omnia Abdelazeem abdelhaleem Hilal

6/5/1/ Questionnaire design: the questionnaire consists of 46 statements. Respondents were first asked about the smartphone brand they own, duration of this ownership, and have been asked if they have more than one brand to choose one and answer the questionnaire about it. Statement 1 to 6 was used to measure brand awareness. Statements from 7 to 34 are used to measure respondents' psychographics. Statements from 35 to 46 are used to measure perceived social media marketing activities. Social media marketing and psychographics statements will be answered by brand page followers only as experimental group members.

A panel of judges has attested to the content validity of the instrument. This panel consists of 15 university professors from several universities such as Cairo, Ain Shams, Tanta, Mansoura, Alexadria, and Zagazig.

6/5/2/ Goodness of fit: The test of goodness of fit is established through validity and reliability of the measures (Sekaran \& Bougie, 2013). More details are as follows:

- Validity of the measures was approved through pilot study conducted on a convenience sample which comprised of 50 smartphone users in Egypt from the chosen governorates. Confirmatory factor analysis was used to examine the research variables' dimensionality (As shown in table 2). The analysis was performed with AMOS 24 and IBM SPSS 24.

Following Hair et al (2010) to evaluate construct validity, convergent validity was assessed by calculating the standardized factor loadings which are ideal when greater than 0.3 (Guilford, 1961, Brown, 2014).

- Reliability: The most popular test of consistency reliability is the Cronbach's coefficient alpha (Cronbach's alpha; Cronbach, 1946), which is used for multipoint-scaled items. It has been calculated for each variable as a whole and for each sub dimension as shown in table (2). 
The role of Demographics and Psychographics in the relationship ......

Omnia Abdelazeem abdelhaleem Hilal

Table (2): Instrument validity (standardized confirmatory factor-analysis) and reliability (Cronbach' alpha)

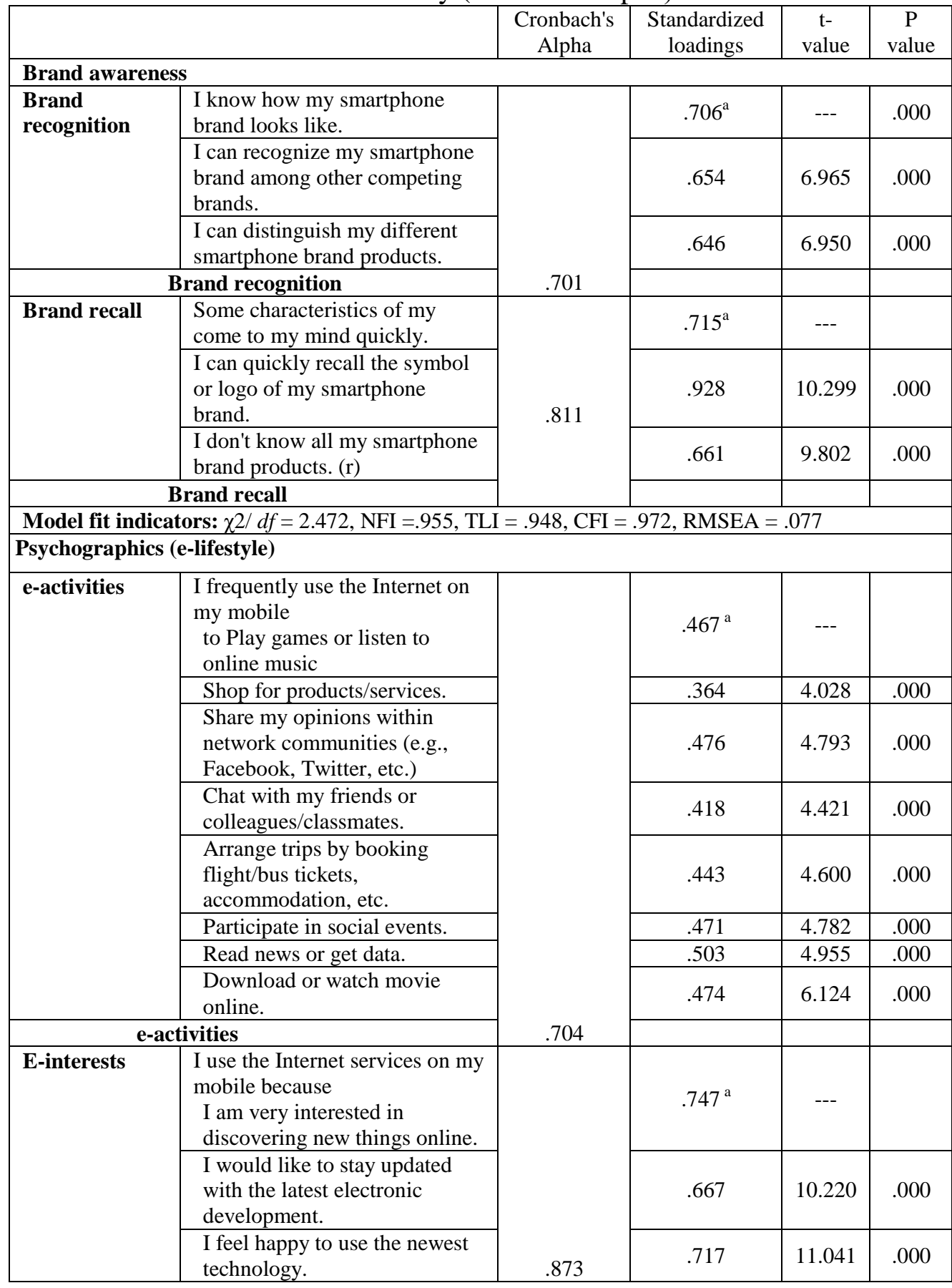


The role of Demographics and Psychographics in the relationship ......

Omnia Abdelazeem abdelhaleem Hilal

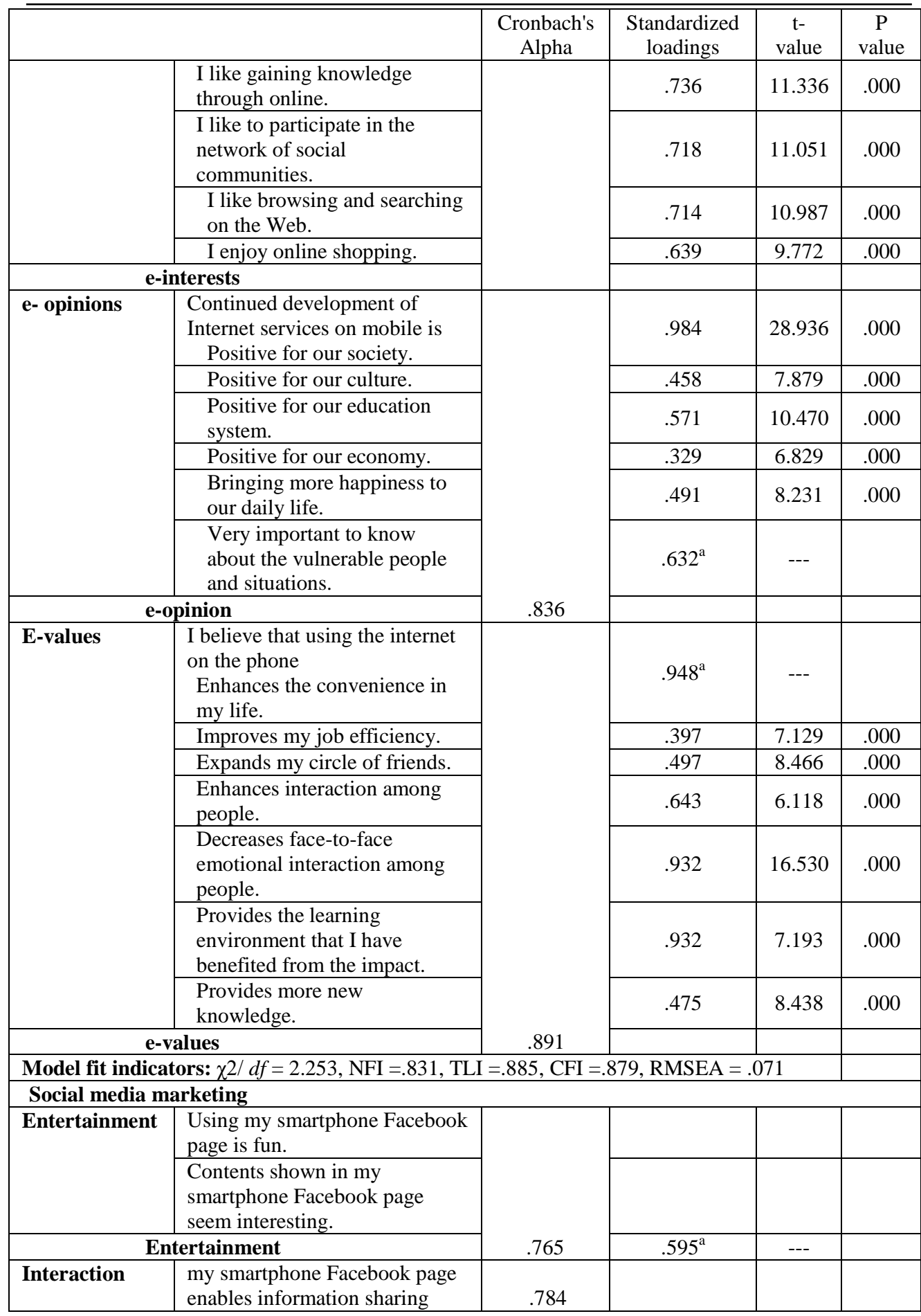


The role of Demographics and Psychographics in the relationship ......

Omnia Abdelazeem abdelhaleem Hilal

\begin{tabular}{|c|c|c|c|c|c|}
\hline & & $\begin{array}{l}\text { Cronbach's } \\
\text { Alpha }\end{array}$ & $\begin{array}{l}\text { Standardized } \\
\text { loadings }\end{array}$ & $\begin{array}{c}\mathrm{t}- \\
\text { value }\end{array}$ & $\begin{array}{c}\mathrm{P} \\
\text { value }\end{array}$ \\
\hline & with others. & & & & \\
\hline & $\begin{array}{l}\text { Conversation or opinion } \\
\text { exchange with others is possible } \\
\text { through my smartphone } \\
\text { Facebook page. }\end{array}$ & & & & \\
\hline & $\begin{array}{l}\text { It is easy to deliver my opinion } \\
\text { through my smartphone } \\
\text { Facebook page. }\end{array}$ & & & & \\
\hline & eraction & & .722 & 8.111 & .000 \\
\hline Trendiness & $\begin{array}{l}\text { Contents shown in my } \\
\text { smartphone Facebook page is } \\
\text { the newest information. }\end{array}$ & & & & \\
\hline & $\begin{array}{l}\text { Using my smartphone Facebook } \\
\text { page is very trendy. }\end{array}$ & & & & \\
\hline & $\begin{array}{l}\text { my smartphone Facebook page } \\
\text { is characterized by quick } \\
\text { response to comments and } \\
\text { complaints }\end{array}$ & & & & \\
\hline & ndiness & .714 & .728 & 8.149 & .000 \\
\hline Customization & $\begin{array}{l}\text { My smartphone Facebook page } \\
\text { provides customized service. }\end{array}$ & & & & \\
\hline & $\begin{array}{l}\text { My smartphone Facebook page } \\
\text { offers customized information } \\
\text { search. }\end{array}$ & & & & \\
\hline & stomization & .764 & .738 & 8.203 & .000 \\
\hline $\begin{array}{l}\text { Word of } \\
\text { mouth }\end{array}$ & $\begin{array}{l}\text { I would like to pass along } \\
\text { information on brand, product, } \\
\text { or services from my smartphone } \\
\text { Facebook page to my friends. }\end{array}$ & & & & \\
\hline & $\begin{array}{l}\text { I would like to upload contents } \\
\text { from my smartphone Facebook } \\
\text { page on my blog or micro blog. }\end{array}$ & & & & \\
\hline & d of mouth & .731 & .676 & 9.286 & .000 \\
\hline $\begin{array}{l}\text { Confirmatory fa } \\
\text { scale consists to } \\
\text { dimensions level } \\
\text { Model fit indica }\end{array}$ & $\begin{array}{l}\text { or analysis has not been applied } \\
\text { vo dimensions with less than } 3 \text { stat } \\
\text { ors: } \chi 2 / d f=1.543, \mathrm{NFI}=.986 \text {, TL }\end{array}$ & $\begin{array}{l}\text { social medi } \\
\text { ments, rather, } \\
=.987, \mathrm{CFI}=\text {. }\end{array}$ & $\begin{array}{l}\text { marketing iter } \\
\text { t has been on a } \\
95, \text { RMSEA }=\end{array}$ & $\begin{array}{l}\text { as the } \\
\text { lied on } \\
77\end{array}$ & \\
\hline $\begin{array}{l}\text { Note: }{ }^{a} \text { Fixed par } \\
\mathrm{P} \text { value is signifi }\end{array}$ & $\begin{array}{l}\text { neters. } \\
\text { ant at less than } 0.001\end{array}$ & & & & \\
\hline
\end{tabular}

It is obvious from the table that all construct items had standardized factor loadings above 0.3 and $\mathrm{T}$ values were significant at 0.01. In general, these results suggest that the theoretical model used was valid. Moreover, the scale in general is reliable as Cronbach alphas recorded more than .07 for the scale items. 
The role of Demographics and Psychographics in the relationship ......

Omnia Abdelazeem abdelhaleem Hilal

Personal interview, online questionnaire, and selfadministered questionnaire were employed to collect primary data from targeted respondents. The researcher has collected the required data during the period March 2018 until June 2018. The data collection plan was achieved and response rates from each governorate are shown in table (3).

Table (3): Response rates

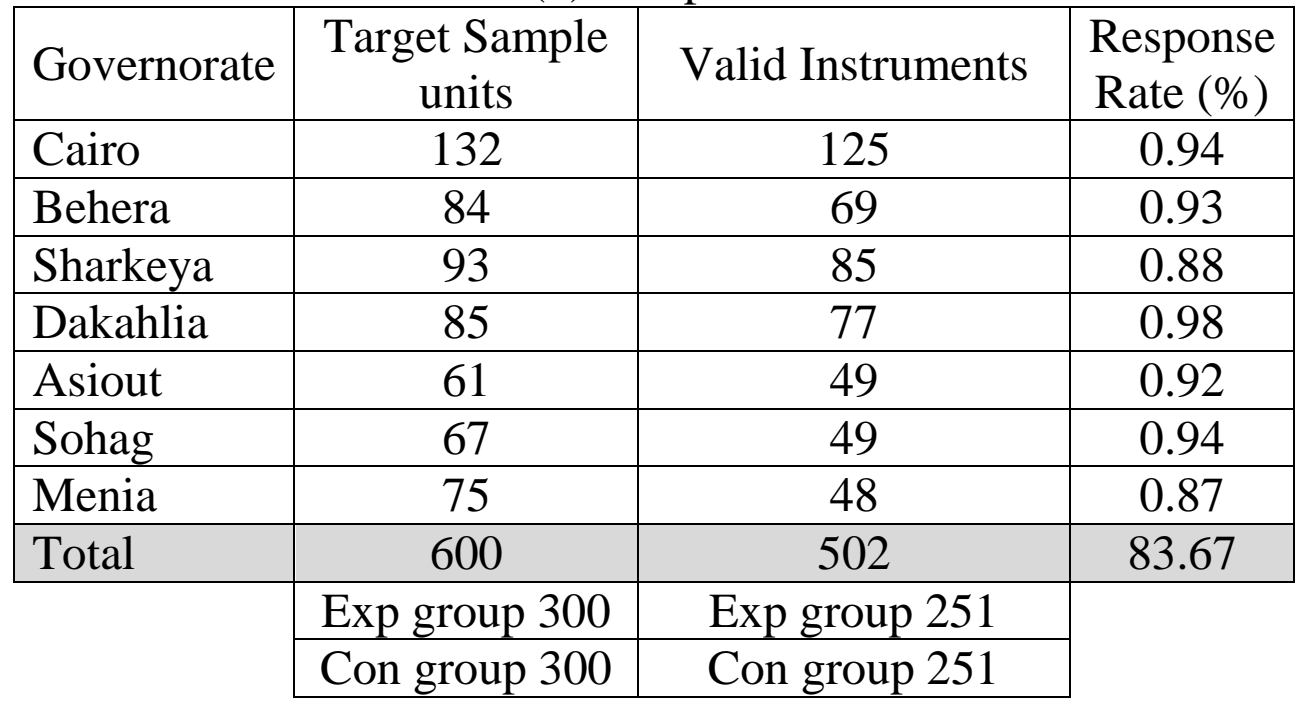

The researcher stopped collecting data after reaching satisfactory response rates from each governorate and an overall response rate. The experimental group consists of 251 respondents of smartphone users in Egypt and so does the control group.

\section{7/ Sample description statistics:}

The sample of the current research constitutes of 502 respondents of smartphone users in Egypt divided into two groups; experimental group (smartphone users who follow their brands page on Facebook) and control group (smartphone users who don't follow their brand pages on Facebook) of 251 respondents each. Follows in table (4) is the experimental and control group demographic descriptive statistics and other descriptive data such as smartphone brand used and period of acquisition. 
The role of Demographics and Psychographics in the relationship ......

Omnia Abdelazeem abdelhaleem Hilal

Table (4): Descriptive statistics of sample respondents $(\mathrm{N}=502)$

\begin{tabular}{|c|c|c|c|c|c|}
\hline \multirow{2}{*}{ Item } & \multirow{2}{*}{ Details } & \multicolumn{2}{|c|}{$\begin{array}{l}\text { Experimental } \\
\text { group }\end{array}$} & \multicolumn{2}{|c|}{ Control group } \\
\hline & & $\begin{array}{c}\text { Frequenc } \\
\mathrm{y}\end{array}$ & $\%$ & $\begin{array}{c}\text { Frequenc } \\
\mathrm{y}\end{array}$ & $\%$ \\
\hline \multirow{6}{*}{$\begin{array}{l}\text { Smartphon } \\
\text { e brand }\end{array}$} & iPhone & 33 & 13.1 & 32 & 12.7 \\
\hline & Samsung & 104 & 41.4 & 94 & 37.5 \\
\hline & Huawei & 55 & 21.9 & 48 & 19.1 \\
\hline & Oppo & 18 & 7.2 & 39 & 15.5 \\
\hline & Other & 41 & 16.3 & 38 & 15.1 \\
\hline & Total & 251 & 100.0 & 251 & 100.0 \\
\hline \multirow{5}{*}{$\begin{array}{l}\text { Period of } \\
\text { acquisition }\end{array}$} & Less than a year & 58 & 23.1 & 44 & 17.5 \\
\hline & $\begin{array}{l}\text { From } 1 \text { year- } 18 \\
\text { months }\end{array}$ & 43 & 17.1 & 59 & 23.5 \\
\hline & $\begin{array}{l}\text { More than } 18- \\
2 \text { years }\end{array}$ & 101 & 40.2 & 98 & 39.0 \\
\hline & $\begin{array}{l}\text { More than } 2 \\
\text { years }\end{array}$ & 49 & 19.5 & 50 & 19.9 \\
\hline & Total & 251 & 100.0 & 251 & 100.0 \\
\hline \multirow[t]{3}{*}{ Gender } & Male & 128 & 51 & 129 & 51.4 \\
\hline & Female & 123 & 49 & 122 & 48.6 \\
\hline & Total & 251 & 100 & 251 & 100 \\
\hline \multirow[t]{6}{*}{ Age } & Less than 20 & 51 & 20.3 & 43 & 17.1 \\
\hline & From 20 to $<30$ & 50 & 19.9 & 62 & 24.7 \\
\hline & From 30 to $<40$ & 54 & 21.5 & 52 & 20.7 \\
\hline & From 40 to $<50$ & 46 & 18.3 & 48 & 19.1 \\
\hline & More than 50 & 50 & 19.9 & 46 & 18.3 \\
\hline & Total & 251 & 100.0 & 251 & 100.0 \\
\hline \multirow{5}{*}{$\begin{array}{l}\text { Marital } \\
\text { status }\end{array}$} & Single & 75 & 29.9 & 76 & 30.3 \\
\hline & Married & 86 & 34.3 & 62 & 24.7 \\
\hline & $\begin{array}{l}\text { Married with } \\
\text { children }\end{array}$ & 60 & 23.9 & 92 & 36.7 \\
\hline & $\begin{array}{l}\text { Divorced/wido } \\
\mathrm{w}\end{array}$ & 30 & 12.0 & 21 & 8.4 \\
\hline & Total & 251 & 100.0 & 251 & 100.0 \\
\hline \multirow{3}{*}{$\begin{array}{l}\text { Income } \\
\text { Pounds/ } \\
\text { Month }\end{array}$} & Less than 3000 & 61 & 24.3 & 95 & 37.8 \\
\hline & 3000 to $<5000$ & 81 & 32.3 & 68 & 27.1 \\
\hline & 5000 to $<10000$ & 48 & 19.1 & 53 & 21.1 \\
\hline
\end{tabular}

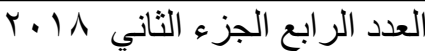


The role of Demographics and Psychographics in the relationship ......

Omnia Abdelazeem abdelhaleem Hilal

\begin{tabular}{|l|l|c|c|c|c|}
\hline \hline \multirow{7}{*}{} & $\begin{array}{l}\text { More than } \\
10000\end{array}$ & 61 & 24.3 & 35 & 13.9 \\
\cline { 2 - 5 } & Total & 251 & 100.0 & 251 & 100.0 \\
\hline Education & $\begin{array}{l}\text { Moderate } \\
\text { education }\end{array}$ & 91 & 36.3 & 40 & 15.9 \\
\cline { 2 - 6 } & $\begin{array}{l}\text { Bachelor's } \\
\text { degree }\end{array}$ & 79 & 31.5 & 158 & 62.9 \\
\cline { 2 - 6 } & $\begin{array}{l}\text { Post bachelor's } \\
\text { degree }\end{array}$ & 81 & 32.3 & 53 & 21.1 \\
\cline { 2 - 6 } & Total & 251 & 100.0 & 251 & 100.0 \\
\hline Occupation & Work full time & 70 & 27.9 & 143 & 57.0 \\
\cline { 2 - 6 } & Don't work & 123 & 49.0 & 59 & 23.5 \\
\cline { 2 - 6 } & $\begin{array}{l}\text { Work partial } \\
\text { time }\end{array}$ & 58 & 23.1 & 49 & 19.5 \\
\cline { 2 - 6 } & Total & 251 & 100.0 & 251 & 100.0 \\
\hline
\end{tabular}

As shown in the table, respondents were using several smartphone brands where the majority used Samsung (41.4\% of the experimental group and $37.5 \%$ of the control group). Concerning periods of acquisition, $40.2 \%$ of respondents of the experimental group and $39.0 \%$ of the control group were using the mobile brand for more than 18 months- 2 years. Of the experimental group, $51 \%$ were male and $49 \%$ were females while $51.4 \%$ were males and $48.6 \%$ were females in the control group.

Moreover, most respondents of the experimental group (21.5\%) were between 30-40 years old most of the control group (24.7\%) were between 20-30 years old. Most respondents of the experimental group $(34.3 \%)$ were married while the majority (36.7\%) of the control group respondents was married with children. The majority of respondents of the experimental group (32.3\%) were gaining monthly income by Egyptian Pound 30005000 while $37.8 \%$ of the control group were gaining monthly income by Egyptian Pound less than 3000. The majority of respondents of the experimental group (36.3\%) had moderate education while $62.9 \%$ of the control group had bachelor's degrees. The majority of respondents of the experimental group 
The role of Demographics and Psychographics in the relationship ......

Omnia Abdelazeem abdelhaleem Hilal

(49\%) don't work while the majority of the of the control group $(57 \%)$ were working full time.

\section{8/ Descriptive statistics:}

The mean, standard deviation, and coefficient of variation have been calculated for each of the variables and for each subdimension of the variables. Table (5) shows variables' descriptive statistics.

Table (5): Variables' descriptive statistics $(n=251$ for each

\begin{tabular}{|l|c|c|c|c|c|c|}
\multicolumn{1}{|c}{ Variables } & \multicolumn{2}{|c|}{ Experimental group } & \multicolumn{3}{c|}{ Control group } \\
\cline { 2 - 7 } & Mean & $\begin{array}{c}\text { Standard } \\
\text { Deviatio } \\
\mathrm{n}\end{array}$ & Variation & Mean & $\begin{array}{c}\text { Standard } \\
\text { Deviation }\end{array}$ & $\begin{array}{c}\text { Variatio } \\
\mathrm{n}\end{array}$ \\
\hline $\begin{array}{l}\text { Brand } \\
\text { recognition }\end{array}$ & $\mathbf{3 . 8 4 9 9}$ & .79334 & .629 & 3.2922 & .71466 & .511 \\
\hline Brand recall & 3.7317 & .87824 & .771 & $\mathbf{3 . 3 1 2 1}$ & .73424 & .539 \\
\hline $\begin{array}{l}\text { Brand } \\
\text { awareness }\end{array}$ & $\mathbf{3 . 7 9 0 8}$ & $\mathbf{. 6 5 8 2 5}$ & $\mathbf{. 4 3 3}$ & $\mathbf{3 . 3 0 2 1}$ & $\mathbf{. 6 4 2 2 4}$ & $\mathbf{. 4 1 2}$ \\
\hline E-Activities & 3.7141 & .67004 & .449 & --- & --- & --- \\
\hline E-Interests & 4.0262 & .67658 & .458 & --- & --- & --- \\
\hline E- Opinions & $\mathbf{4 . 2 2 3 1}$ & .63493 & .403 & --- & --- & --- \\
\hline E-Values & 4.0085 & .64016 & .410 & --- & --- & --- \\
\hline Psychographics & 3.9748 & .51379 & .264 & --- & --- & --- \\
\hline Entertainment & 3.6275 & .88073 & .776 & --- & --- & --- \\
\hline Interaction & $\mathbf{3 . 7 0 5 2}$ & .89235 & .796 & --- & --- & --- \\
\hline Trendiness & 3.5963 & .82619 & .683 & --- & --- & --- \\
\hline Customization & 3.6892 & .82767 & .685 & --- & --- & --- \\
\hline Word of Mouth & 3.2829 & 1.1196 & 1.254 & --- & --- & --- \\
\hline $\begin{array}{l}\text { Social media } \\
\text { marketing }\end{array}$ & 3.5920 & .69784 & .487 & --- & --- & --- \\
\hline
\end{tabular}

As shown in the previous table, respondents of the experimental group indicated high levels of mean score for social media marketing (mean=3.5920, $\mathrm{SD}=.69784$ ). Brand recall of experimental group respondents recorded lower mean score (mean $=3.7317, \mathrm{SD}=.87824$ ) than brand recognition (mean= $3.8499, \mathrm{SD}=.79334$ ) which means that the brand name is well established in consumers' minds, they can associate its attributes, and can identify the brand under a variety of circumstances, but 
The role of Demographics and Psychographics in the relationship ......

Omnia Abdelazeem abdelhaleem Hilal

they cannot recall it when the brand is not present in decisionmaking situations.

Next, a correlation matrix of all variables has been developed and used to test the hypothesis and the results are shown in table (6).

Table (6): Correlation Matrix of research variables

\begin{tabular}{|l|l|c|c|c|c|c|}
\hline \multicolumn{2}{|c|}{ Variables } & Mean & SD & $\mathbf{1}$ & $\mathbf{2}$ & $\mathbf{3}$ \\
\hline 1 & $\begin{array}{l}\text { Social media } \\
\text { marketing }\end{array}$ & 3.5920 & .69784 & 1 & & \\
\hline 2 & Brand awareness & 3.7908 & .65825 & $.595^{* *}$ & 1 & \\
\hline 3 & Psychographics & 3.9748 & .51379 & $.674^{* *}$ & $.751^{* *}$ & 1 \\
\hline \multicolumn{6}{|c|}{ * Correlation is significant at the 0.01 level (2-tailed). }
\end{tabular}

Note: Numbers 1-3 in the top row represent the variables as mentioned in the first column.

As shown in the previous table, Pearson correlation coefficients have been used to measure how strong the relationship is between the research variables. Correlation coefficients for social media marketing and brand awareness and psychographics recorded $.595^{* *}$ and $.674^{* *}$ respectively $(\mathrm{p}<.01)$.

Next, the researcher calculated several statistical techniques to test the research hypotheses as follows.

\section{9/ Hypothesis testing results:}

This research aimed at testing 3 hypotheses; following is the procedures undertaken to test these hypotheses.

\section{9/1/ The effect of social media marketing on brand awareness:}

The first hypothesis has been tested after executing two steps; (1) comparing the mean scores of brand awareness for the two groups (experimental and control), and (2) regression analysis. After executing these two types of analysis, results are discussed.

\section{9/1/1 Independent-samples t-test:}

The Independent Samples t-test compares the means of the experimental and control group in order to determine whether 
The role of Demographics and Psychographics in the relationship ......

Omnia Abdelazeem abdelhaleem Hilal

there is statistical evidence that the associated population means (brand awareness) are significantly different. Table (7) shows the results of the independent-samples t-tests.

Table (7): Independent-samples t-test results

\begin{tabular}{|l|c|c|c|c|c|}
\hline \multirow{2}{*}{ Variable } & \multirow{2}{*}{$\mathrm{T}$} & $\mathrm{df}$ & \multicolumn{2}{c|}{ Means } & Sig $\mathrm{p}$ \\
\cline { 4 - 6 } & & Experiment & Control & value \\
\hline $\begin{array}{l}\text { Brand } \\
\text { awareness }\end{array}$ & 8.419 & 500 & 3.7908 & 3.3021 & 0.000 \\
\hline
\end{tabular}

As shown above, $\mathrm{p}$ value is lower than the required cut-off of .05 for the brand awareness; $(t=8.419)$, thus, it is indicated that there is a statistically significant difference in the mean of brand awareness among smartphone users in Egypt scores between experimental group and control group. This difference is for the social media marketing group. Brand awareness of the experimental group recorded 3.7908 while the control group's recorded 3.3021.

\section{9/1/2/ Regression Analysis:}

Regression analysis has been conducted to ensure the previously shown results (independent samples t-test) that social media marketing significantly affects brand awareness among smartphone users in Egypt. Table (8) shows simple regression analysis results (Model fit indicators: $\chi 2 / d f=2.253$, NFI $=.831$, $\mathrm{TLI}=.885$, CFI $=.879$, RMSEA $=.071)$.

Table (8): Simple regression analysis results of

social media marketing on brand awareness.

\begin{tabular}{|l|c|}
\hline Items & Value \\
\hline Beta & $\mathbf{. 5 9 5}$ \\
\hline C.R. (T) & 22.690 \\
\hline Sig & .000 \\
\hline R $^{2}$ & .353 \\
\hline S.E. & .024 \\
\hline
\end{tabular}

As shown, social media marketing has a significant effect on brand awareness $(\beta=.595$, C.R. $=22.690$, sig=.00). In other 
The role of Demographics and Psychographics in the relationship ......

Omnia Abdelazeem abdelhaleem Hilal

words, social media marketing explains 36\% of the variances in brand awareness among smartphone users in Egypt.

In sum, the current research results showed that social media marketing significantly affects brand awareness among smartphone users in Egypt as there is a significant difference between means of brand awareness of experimental and control group as well as the significant regression coefficients for social media marketing and brand awareness among smartphone users in Egypt. It is concluded that social media marketing has significantly affected brand awareness among smartphone users in Egypt.

As there is still a debate about the effect of social media marketing on brand awareness between the two sides (opponents and supporters), the role of demographics and psychographics will be tested to clarify this debate.

\section{9/2/ The effect of Demographics:}

To test the second, multi group analysis using SPSS Amos 24 has been employed. The samples were splitted into subsamples according to demographic features (e.g., males versus females, age groups., etc) to ensure within-group homogeneity and between group heterogeneity. The subgroup method is a commonly preferred technique for detecting moderating effects and has been extensively used in the literature (e.g., Wulf et al., 2001; Homburg and Giering, 2001; Brockman and Morgan, 2006; Khan \& Rahman, 2016; Karikari, OseiFrimpong, \& Owusu-Frimpong, 2017).

\section{9/2/1/ The effect of gender:}

Table (9) shows the effect of gender on the relationship between social media marketing and brand awarenessamong smartphone users in Egypt. 
The role of Demographics and Psychographics in the relationship ......

Omnia Abdelazeem abdelhaleem Hilal

Table (9): The effect of gender on the relationship between social media

marketing and brand awareness.

\begin{tabular}{|l|c|c|c|c|c|c|c|}
\hline & Gender & $\mathrm{R}^{2}$ & S.E. & $\beta$ & C.R. & Sig & $\begin{array}{c}\text { Critical ratio } \\
\text { of difference }^{\#}\end{array}$ \\
\hline $\begin{array}{l}\text { SMM on } \\
\text { brand } \\
\text { awareness }\end{array}$ & Female & .329 & .037 & .574 & 7.743 & .000 & \multirow{2}{*}{-.081} \\
\cline { 2 - 7 } & Male & .379 & .032 & .616 & 8.809 & .000 & \\
\hline
\end{tabular}

\#Absolute critical ratios less than 1.96 are insignificant.

Absolute critical ratios more than 1.96 are significant.

Coefficients of determination between Social media marketing and brand awareness are more for males $\left(\mathrm{R}^{2}=.379\right)$ than females $\left(\mathrm{R}^{2}=.329\right)$. This implies that male respondents depend more on social media marketing than female respondents and social media marketing is more correlated with brand awareness for male group than female respondents.

It is also shown in table (9) that the critical ratio for differences between males and females are lower than 1.96 (.081) for the relationship between social media marketing and brand awareness) which means that social media marketing effect on brand awareness for male respondents is the same as female respondents. It is concluded that, although correlation and regression coefficients varied between males and females, multi group analysis showed that gender does not affect the relationship between social media marketing and brand awareness.

\section{9/2/2/ The effect of age:}

Table (10) shows the effect of age on the relationship between social media marketing and brand awareness.

Table (10): The effect of age on the relationship between social media marketing and brand awareness.

\begin{tabular}{|l|c|c|c|c|c|c|c|c|c|c|}
\hline \multirow{2}{*}{ Age } & \multirow{2}{*}{$\mathrm{R}^{2}$} & \multirow{2}{*}{ S.E. } & \multirow{2}{*}{$\beta$} & critical & \multirow{2}{*}{ sig } & \multicolumn{5}{|c|}{ Critical ratio of difference } \\
\cline { 6 - 10 } & & & & ratio & & $(1)$ & $(2)$ & $(3)$ & $(4)$ & $(5)$ \\
\hline$(1)$ & .119 & .057 & .345 & 2.596 & .009 & --- & & & & \\
\hline$(2)$ & .017 & 0.71 & .129 & .913 & .361 & .926 & --- & & & \\
\hline
\end{tabular}


The role of Demographics and Psychographics in the relationship ......

Omnia Abdelazeem abdelhaleem Hilal

\begin{tabular}{|c|c|c|c|c|c|c|c|c|c|c|}
\hline (3) & .002 & .073 &. & -.291 & .771 & 1.833 & -.845 & --- & & \\
\hline (4) & .013 & .580 & $\begin{array}{c}- \\
.112\end{array}$ & -.757 & .449 & $\begin{array}{c}- \\
2.364\end{array}$ & $\begin{array}{c}- \\
1.186\end{array}$ & -.243 & --- & \\
\hline (5) & .114 & .050 & .338 & 2.513 & .012 & -.297 & .711 & 1.665 & 2.218 & -- \\
\hline
\end{tabular}

(1) Less than 20 years old

(2) 20-30 years old

(3) 30-40 years old

(4) 40-50 years old

(5) More than 50 years old

\#Absolute critical ratios less than 1.96 are insignificant.

Absolute critical ratios more than 1.96 are significant.

Coefficients of determination and regression of social media marketing and brand awareness varied greatly across age groups. Respondents who are less than 20 years old recorded the highest coefficients of determination and regression $(\mathrm{R} 2=.119$, $\beta=.345$ ) followed by respondents who are more than 50 years $(\mathrm{R} 2=114, \beta=.338)$, other age groups recorded insignificant coefficients of determination and regression. Surprisingly, age group (more than 50 years old) represents a generation that is used to depend on traditional media such as TV, newspapers, fliers, etc. recorded very high coefficients of determination and regression.

As shown in table (10), some of the critical ratios for differences among age groups are significant while others aren't. Respondents who are less than 20 years old are significantly different from respondents who are 40-50 years old (critical ratio=-2.364), respondents who are between 40-50 are significantly different from respondents who are more than 50 years old (critical ratio $=2.218$ ) which means that social media marketing effect on brand awareness is significantly different across age groups.

Based on multi group analysis, it is concluded that age affects the relationship between social media marketing and brand awareness among smartphone users in Egypt.

\section{9/2/3/ The effect of marital status:}

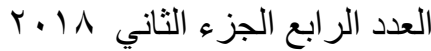

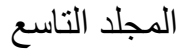


The role of Demographics and Psychographics in the relationship ......

Omnia Abdelazeem abdelhaleem Hilal

Table (11) shows the effect of marital status on the relationship between social media marketing and brand awareness among smartphone users in Egypt.

Table (11): The effect of marital status on the relationship

between social media marketing and brand awareness.

\begin{tabular}{|l|c|c|c|c|c|c|c|c|c|}
\hline & $\mathrm{R}^{2}$ & S.E. & $\beta$ & $\begin{array}{c}\text { Critical } \\
\text { ratio }\end{array}$ & sig & Single & Married $\begin{array}{c}\text { Married } \\
\text { with } \\
\text { children }\end{array}$ & $\begin{array}{c}\text { Widow/ } \\
\text { divorced }\end{array}$ \\
\hline Single & .325 & .048 & .570 & 5.961 & .00 & --- & & & \\
\hline Married & .375 & .036 & .612 & 7.121 & .00 & -.516 & --- & & \\
\hline $\begin{array}{l}\text { Married } \\
\text { with } \\
\text { children }\end{array}$ & .328 & .050 & .573 & 5.368 & .00 & -.305 & .162 & --- & \\
\hline $\begin{array}{l}\text { Widow/ } \\
\text { divorced }\end{array}$ & .426 & .073 & .653 & 4.683 & .00 & .593 & 1.022 & .828 & --- \\
\hline
\end{tabular}

Absolute critical ratios less than 1.96 are insignificant.

Absolute critical ratios more than 1.96 are significant.

Coefficients of determination and regression for social media marketing and brand awareness recorded $\left(\mathrm{R}^{2}=0.353\right.$ and $\beta=.605)$. Meanwhile when marital status is taken into consideration, coefficients of correlation and regression between social media marketing and brand loyalty varied. All marital status groups recorded significant coefficients of determination and regression. Social media marketing and brand loyalty coefficients of determination and regression for divorced/ widow respondents recorded the highest coefficients $\left(\mathrm{R}^{2}=.426\right.$, $\beta=.653)$ followed by married respondents $\left(\mathrm{R}^{2}=.375, \beta=.612\right)$ and coefficients for singles recorded the lowest $\left(\mathrm{R}^{2}=.325\right.$, $\beta=.570)$. It noted that coefficients of determination and regression are higher for widow/divorced respondents. This might be due to the much available time for them and the desire to know more through this media.

As shown in table (11), all the critical ratios for differences among marital status groups are insignificant which 
The role of Demographics and Psychographics in the relationship ......

Omnia Abdelazeem abdelhaleem Hilal

means that single respondents are equal to married, married with children, and widow/divorced respondents. In other words, social media marketing effect on brand awareness is insignificantly different across marital status groups.

Based on multi group analysis, it is concluded that marital status doesn't affect the relationship between social media marketing and brand awareness among smartphone users in Egypt.

\section{9/2/4/ The effect of income:}

Table (12) shows the effect of income on the relationship between social media marketing and brand awareness among smartphone users in Egypt.

Table (12): The effect of income on the relationship between social media marketing and brand awareness.

\begin{tabular}{|c|c|c|c|c|c|c|c|c|c|}
\hline & \multirow[b]{2}{*}{$\mathrm{R}^{2}$} & \multirow[b]{2}{*}{ S.E. } & \multirow[b]{2}{*}{$\beta$} & \multirow[b]{2}{*}{$\begin{array}{l}\text { Critica } \\
1 \text { Ratio }\end{array}$} & \multirow[b]{2}{*}{ sig } & \multicolumn{4}{|c|}{ Critical ratio of difference\# } \\
\hline & & & & & & $\begin{array}{l}\text { Less } \\
\text { than } \\
3000\end{array}$ & $\begin{array}{l}3000- \\
5000\end{array}$ & $\begin{array}{l}5000- \\
10000\end{array}$ & $\begin{array}{l}\text { More } \\
\text { than } \\
10000\end{array}$ \\
\hline $\begin{array}{l}\text { Less than } \\
3000\end{array}$ & .143 & .051 & .378 & 3.162 & .002 & --- & & & \\
\hline $3000-5000$ & .001 & .061 & -.031 & -.273 & .785 & -2.243 & --- & & \\
\hline $\begin{array}{l}5000- \\
10000\end{array}$ & .000 & .071 & -.003 & -.230 & .981 & -1.868 & .160 & --- & \\
\hline $\begin{array}{l}\text { More than } \\
10000\end{array}$ & .114 & .048 & .338 & 2.784 & .005 & .373 & 1.961 & 1.593 & --- \\
\hline
\end{tabular}

\# Absolute critical ratios less than 1.96 are insignificant.

Absolute critical ratios more than 1.96 are significant.

Coefficients of determination and regression of social media marketing and brand awareness are partially significant and varied greatly across income groups. It is noted that coefficients of determination and regression of social media marketing and brand awareness is the highest for respondents with less than 3000 pounds monthly income $\left(\mathrm{R}^{2}=.143, \beta=.378\right)$, lowest for More than 10000 groups $\left(\mathrm{R}^{2}=.114, \beta=.3 \mathrm{r} 8\right)$, insignificant for the rest. 
The role of Demographics and Psychographics in the relationship ......

Omnia Abdelazeem abdelhaleem Hilal

As shown in table (12), some of the critical ratios for differences among income groups are significant while others are not. Respondents with income less than 3000 L.E. are significantly different from those with 3000-5000 L.E. (critical ratio $=-2.243$ ). respondent with 3000-5000 L.E. are different from respondents with more than 10000 L.E. (critical ratio= 1.961). It is implied that social media marketing effect on brand awareness is significantly different across income groups.

Based on multi group analysis, it is concluded that income affects the relationship between social media marketing and brand awareness among smartphone users in Egypt.

\section{9/2/5/ The effect of education:}

Table (13) shows the effect of education on the relationship between social media marketing and brand awareness among smartphone users in Egypt.

Table (13): The effect of education on the relationship

between social media marketing and brand awareness.

\begin{tabular}{|l|c|c|c|c|c|c|c|c|}
\hline & \multirow{2}{*}{$\mathrm{R}^{2}$} & S.E. & $\beta$ & $\begin{array}{c}\text { critical } \\
\text { ratio }\end{array}$ & sig & Moderate & $\begin{array}{c}\text { University } \\
\text { degree }\end{array}$ & $\begin{array}{c}\text { Higher } \\
\text { than } \\
\text { university }\end{array}$ \\
\hline Moderate & .234 & .041 & .484 & 5.247 & .000 & --- & & \\
\hline $\begin{array}{l}\text { University } \\
\text { degree }\end{array}$ & .000 & .056 & .020 & .179 & .858 & $\mathbf{- 2 . 9 6 9}$ & --- & \\
\hline $\begin{array}{l}\text { Higher } \\
\text { than } \\
\text { university }\end{array}$ & .090 & .046 & .301 & 2.820 & .005 & -1.403 & 1.652 & --- \\
\hline
\end{tabular}

Absolute critical ratios less than 1.96 are insignificant.

Absolute critical ratios more than 1.96 are significant.

Coefficients of determination and regression of social media marketing and brand awareness are partially significant and varied greatly across income groups. It is noted that coefficients of determination and regression of social media marketing and brand awareness is the highest for respondents with moderate education $\left(\mathrm{R}^{2}=.234, \beta=.484\right)$, lowest for Higher 
The role of Demographics and Psychographics in the relationship ......

Omnia Abdelazeem abdelhaleem Hilal

than university groups $\left(\mathrm{R}^{2}=.090, \beta=.301\right)$, insignificant for the university degree holders.

As shown in table (13), some of the critical ratios for differences among education groups are significant while other are insignificant. Respondents with moderate education are significantly different from respondents with university degree (critical ratio=-2.969). In other words, social media marketing effect on brand awareness is significantly different across education groups.

Based on multi group analysis, it is concluded that education affects the relationship between social media marketing and brand awareness among smartphone users in Egypt.

\section{9/2/6/ The effect of occupation:}

Table (14) shows the effect of occupation on the relationship between social media marketing and brand awareness among smartphone users in Egypt.

Table (14): The effect of occupation on the relationship

between social media marketing and brand awareness.

\begin{tabular}{|l|c|c|c|c|c|c|c|c|}
\hline & & & & & & \multicolumn{3}{|c|}{ Critical ratio of } \\
\cline { 6 - 9 } & $\mathrm{R}^{2}$ & S.E. & $\beta$ & $\begin{array}{c}\text { critical } \\
\text { ratio }\end{array}$ & sig & $\begin{array}{c}\text { Work } \\
\text { full } \\
\text { time }\end{array}$ & $\begin{array}{c}\text { Don't } \\
\text { work }\end{array}$ & $\begin{array}{c}\text { Work } \\
\text { partially }\end{array}$ \\
\hline $\begin{array}{l}\text { Work full } \\
\text { time }\end{array}$ & .372 & .048 & .610 & 6.405 & .000 & --- & & \\
\hline $\begin{array}{l}\text { Don't } \\
\text { work }\end{array}$ & .304 & .035 & .552 & 7.290 & .000 & -.921 & --- & \\
\hline $\begin{array}{l}\text { Work } \\
\text { partially }\end{array}$ & .436 & .044 & .661 & 6.661 & .000 & -.257 & .679 & --- \\
\hline
\end{tabular}

" Absolute critical ratios less than 1.96 are insignificant.

Absolute critical ratios more than 1.96 are significant.

It is noted that coefficients of determination and regression of social media marketing and brand awareness are significant and varied across occupation groups. They are the highest for 
The role of Demographics and Psychographics in the relationship ......

Omnia Abdelazeem abdelhaleem Hilal

respondents who work partial time $\left(\mathrm{R}^{2}=.436, \beta=.661\right)$, lowest for respondents with higher than university groups $\left(\mathrm{R}^{2}=.304, \beta=.552\right)$.

As shown in table (14), all the critical ratios for differences among occupation groups are insignificant which means that respondents who work full time are equal to respondents who don't work or who work partial time. In other words, social media marketing effect on brand awareness is insignificantly different across occupation groups.

Based on multi group analysis, it is concluded that there are no differences among occupation groups, therefore occupation doesn't affect the relationship between social media marketing and brand awareness.

It is obvious from the previous results that some of the demographics (age, income, and education) affect the relationship between social media marketing and brand awareness while others don't (gender, marital status, and occupation). Therefore, hypotheses 3, 5, and 6 are accepter while hypotheses 2, 4, and 7 are rejected.

\section{9/3/ The role of psychographics:}

The role of psychographics has been explored through a test of path analysis for the direct and indirect relationships between social media marketing and brand awareness among smartphone users in Egypt. Amos and IBM SPSS 22 have been used. After showing the analysis results, a discussion is presented.

Path analysis was employed to test the research hypothesis no.3 which states that psychographics affect the relationship between social media marketing and brand awareness among smartphone users in Egypt. 


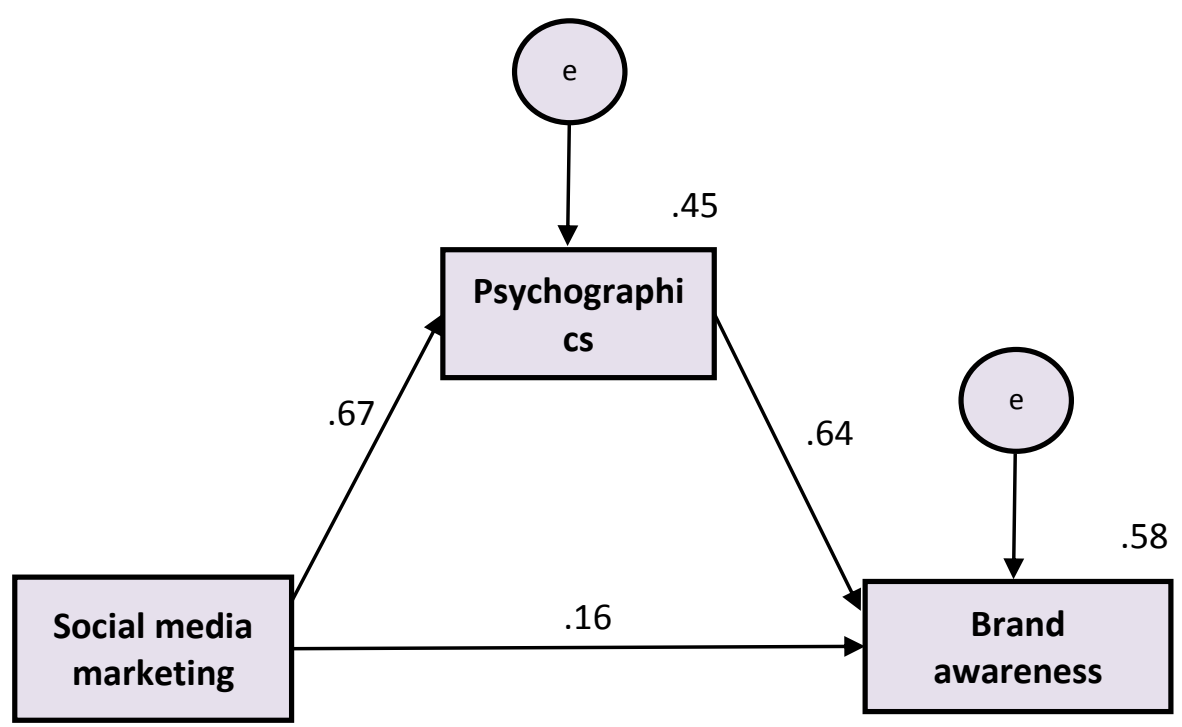

Figure (2) shows the effect of psychographics on the relationship between social media marketing on brand awareness among smartphone users Egypt. The overall fit of the structural model to the data was highly acceptable $(\chi 2 / \mathrm{df}=---, \mathrm{CFI}=1$, $\mathrm{NFI}=1$, TLI $=--$, RMSEA=--).

Figure (2): The role of psychographics in the relationship

between social media marketing and brand awareness.

It is obvious from the previous figure that the indirect effect of social media marketing on brand awareness through psychographics is stronger than the direct effect. As shown in figure (2), social media marketing direct effect recorded .16 while the indirect effect through psychographics recorded .64.

Table (15) shows the hypothesis testing and path analysis results.

Table (15): Results of hypothesis testing and path analysis.

\begin{tabular}{|l|c|c|c|c|c|}
\hline \multicolumn{1}{|c|}{ Paths } & $\beta$ & Estimate & S.E. & C.R. & P(sig) \\
\hline SMM* ---> Brand Awareness $^{*} .162$ & .077 & .026 & 2.919 & .004 \\
\hline SMM ---> Psychographics & .674 & 1.158 & .080 & 14.423 & .000 \\
\hline
\end{tabular}


The role of Demographics and Psychographics in the relationship ......

Omnia Abdelazeem abdelhaleem Hilal

\begin{tabular}{|l|c|c|c|c|c|}
\hline \multicolumn{1}{|c|}{ Paths } & $\beta$ & Estimate & S.E. & C.R. & P(sig) \\
\hline $\begin{array}{l}\text { Psychographics ---> Brand } \\
\text { Awareness }\end{array}$ & .641 & .176 & .015 & 11.529 & .000 \\
\hline
\end{tabular}

* Social Media Marketing.

It is obvious from the previous table that the indirect relationshipbetween social media marketing and brand awareness is significant as regression weight estimate (CR) values for the path are more than 2.54. Moreover, the p value (.000) indicates that the regression weight for social media marketing in the prediction of brand awareness is significantly different from zero at the 0.001 level (two-tailed). Therefore, psychographics significantly affect the relationship between social media marketing and brand awareness among smartphone users in Egypt. Accordingly, hypothesis 8 is accepted.

Table (16) shows summary of hypotheses testing results.

Table (16): Summary of hypotheses testing results.

\begin{tabular}{|c|l|c|}
\hline No. & \multicolumn{1}{|c|}{ Hypothesis } & Decision \\
\hline 1 & SMM ---> Brand Awareness & Accepted \\
\hline 2 & Gender effect & Denied \\
\hline 3 & Age effect & Accepted \\
\hline 4 & Marital status effect & Denied \\
\hline 5 & Income effect & Accepted \\
\hline 6 & Education effect & Accepted \\
\hline 7 & Occupation effect & Denied \\
\hline 8 & Psychographics affect SMM---> Brand Awareness & Accepted \\
\hline
\end{tabular}

\section{0/ Discussion and conclusions:}

The current research results showed that social media marketing significantly affects brand awareness among smartphone users in Egypt as there is a significant difference between means of brand awareness of experimental and control group as well as the significant regression coefficients for social media marketing and brand awareness among smartphone users in Egypt. The current research results concerning the effect of social media marketing and brand awareness are consistent with 
The role of Demographics and Psychographics in the relationship ......

Omnia Abdelazeem abdelhaleem Hilal

Hutter et al (2013), Barwise \& Meehan (2010), Barreda et al (2015), Keller, 2009; Swani et al (2013), Malhotra, Malhotra \& See (2013), Muñiz \& Schau (2011) and Thoring (2011). However, the current research opposed the results of Hames (2009), Dziadul (2010), La Pointe (2012), and Bruhn, Schoenmueller, \& Schäfer (2012).

Several factors can interpret this result. First, one of the main online brand-related activities is entrainment (Vale \& Fernandes, 2018), smartphone users in Egypt found their brand platforms entertaining as the mean of entertainment recorded 3.6275. Smartphone brand owners made their interactions creative \& funny to attract browser's attention, increase traffic, and increase exposure which finally enhanced their awareness with their smartphone brand.

Second, interaction as a dimension of social media marketing has significantly influenced smartphone users' awareness as its mean recorded 3.7908. Social media has created a totally new level of interaction between brands and consumers and consumers themselves. Conversations and talk between the two sides have enabled brand owners to build instant relationship and have the unique opportunity to communicate on a personal level with their customers which finally helped businesses to effectively get their followers more aware on social media; recognize their smartphone brand among other competing brands, and distinguish my different smartphone brand products.

Third, in an ever changing and updated world, trendiness (mean=3.5963) has forced itself and played a significant role nowadays where smartphone users found their brand pages continuously updated and respond to their feedback in a timely manner which finally enhanced brand awareness. Often, customers are taking to social media with complaints where 78.5 $\%$ people express their sentiments or views (e.g. satisfaction, happiness, disapproval, anger, etc.) when using social media

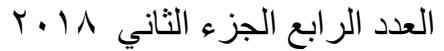

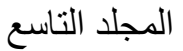


The role of Demographics and Psychographics in the relationship ......

Omnia Abdelazeem abdelhaleem Hilal

(Arab Social Media Report, 2017), mobile brands had a plan to respond to complaints in the right way and on the right time.

Forth, information seeking is one of the main activities of Facebook users when browsing their brand pages. Customization mean recorded 3.6892 which means that social media marketing of smartphone brands established dialogues between marketers and consumers and among consumers, extensive spread of news, descriptions, manuals, images, which all contributed in the creation of brand recognition and recall.

Fifth, smartphone brands social media marketing has created a whole new level of word of mouth. Social media had been best used to reach consumers directly; certainly, those consumers can also reach other consumers, which create electronic word of mouth on which consumers rely because peer recommendations are credible and trustworthy, which has been finally enhanced smartphone brands awareness.

Results showed that psychographics significantly affect the relationship between social media marketing and brand awareness among smartphone users in Egypt. Several factors can interpret this result. Psychographics pertain to people's lifestyle (activities, interests, opinions and values). Lifestyle is viewed as a summary concept that offers the possibility of new insights, unusual conclusions, and provides "a broader, more threedimensional view of the consumers" (Hawes, 1978). These are a key to understanding motivations and why people do what they do.

Smartphone brands owners were able to understand these kinds of psychographic differences and as a result, social media marketing tools made psychographic insights actionable in a way that was nearly impossible before. Using psychographics allowed marketers to do smarter keyword targeting - for example, targeting one message about the new smartphone with specific features to browsers who recently searched for

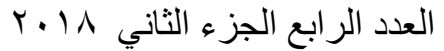

المجلد التناسع 
The role of Demographics and Psychographics in the relationship ......

Omnia Abdelazeem abdelhaleem Hilal

smartphones with this feature and another message to consumers complaints from smartphones without this feature.

Social media marketing enabled smartphone brands owners to explore browsers' activities, interests, opinions, and values, design marketing messages suitable for each lifestyle category, target these messages for each category easily and effectively. Moreover, social media marketing made these kinds of psychographic differences much more apparent and relevant to both consumers and marketers alike. The social media has changed the relative importance of psychographics to marketers in three key ways: by making psychographics more actionable, by making psychographic differences more important, and by making psychographic insight easier to access. Furthermore, social media presence enabled marketers to influence consumers' lifestyle $(\beta=1.16, \mathrm{P}<.01)$. As mentioned before, marketers can now easily explore fans' lifestyles and tailor marketing efforts to better suit specific categories and even more it enabled marketers to make shifts in consumers' activities and cut consumers' time to newly new activities that had never been done before; share opinions within network communities, chat with friends or colleagues/classmates, participate in social events, or read news or get data.

Moreover, social media marketing has made a shift in consumers' interests from tangible world to virtual settings; consumers would like now to stay updated with the latest electronic development, like gaining knowledge through online, like to participate in the network of social communities, and enjoy online shopping. Furthermore, social media marketing has reversed consumers' opinions from resisting the new mobile technology to believe now that continued development of internet services on mobile is positive for society, culture, economy, and brings happiness to daily life. Finally, social media marketing has transferred consumers' values to the favor of internet applications and made them believe that using the 
The role of Demographics and Psychographics in the relationship ......

Omnia Abdelazeem abdelhaleem Hilal

internet on the phone enhances the convenience in consumers' life, enhances interaction among people, and provides more new knowledge.

All the previous shits in consumers' psychographics accompanied with social media marketing have all enhanced consumers brand awareness. It is now concluded that psychographics affects the relationship between social media marketing and brand awareness.

In sum, research hypotheses have been all tested and results have been discussed. It is concluded that most of the research hypotheses are supported and the research gap concerning the ambiguity of the relationship between social media marketing and brand awareness has been almost clarified by the supported role of demographics and psychographics.

\section{1/Practical implication:}

The main purpose is to help managers to understand the benefits of social media and how they can have an impactful social marketing method and strategy. Therefore, the following practical implications have been made clear.

The current study's investigation of the increasing utilization of social media marketing offers valuable insights on the relative influence of this media on brand awareness compared to traditional media of marketing.social media marketing has the same advantages and benefits and more as offline or the traditional media such as the vast reach, low cost and popularity of social media which are prompting all brand managers to take advantage of such characteristics.The findings in this study underpin the relevance of social media for brand management. While managers may still doubt the usefulness of social media involvements, this study highlighted social media as an important and integral part of the marketing communication strategy. Taking into consideration the creation and management of interaction between brand owners and customers and customers each other can significantly enhance consumers brand awareness. 
The role of Demographics and Psychographics in the relationship ......

Omnia Abdelazeem abdelhaleem Hilal

Social media marketing through the creation of positive word of mouth and the management of negative word of mouth will significantly enhance consumers brand awareness and awareness. When the contents shown in smartphone brand on Facebook page is the newest information and when the page is characterized by quick response to comments and complaints (trendiness), brand owners will definitely achieve greater awareness ofsmartphone users in Egypt.Surprisingly; if the brand page is providing entertaining contentand customized services, enhancing brand awareness among smartphone users in Egypt is not assured. It is not enough for marketing managers to simply measure and enhance brand awareness among smartphone users in Egypt through social media marketing in isolation from demographics.

Targeting social media marketing messages with the final aim of enhancing brand awarenessamong smartphone users in Egypt to specific groups based on their age, income, and education makes marketers work more efficiently. It is not sufficient for marketing managers to simply measure and enhance brand awarenessthrough social media marketing in isolation from psychographics. Targeting social media marketing messages with the final aim of enhancing brand awareness to specific smartphone users' groups based on their activities, interests, opinions, and values makes marketers work more efficient.

The strategic implementation of social media marketing offers marketers an added advantage in being relatively low in investment costs compared to traditional marketing communication instruments such as TV. Smartphone brands owners can use social media activities mostly as means to gather information, learn about consumers and their attitude towards the products and the brand, and can have positive economic effects for the brand and the company.

\section{2/ limitations and Future research:}

In spite of the importance of the current research results, there

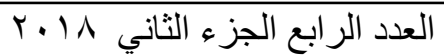

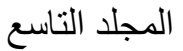


The role of Demographics and Psychographics in the relationship ......

Omnia Abdelazeem abdelhaleem Hilal

are some limitations. Based on these limitations, several future research areas are suggested. First, the current research had focused on brand awareness as one of the consequences of social media marketing in smartphones industries context, however, other contexts should be examined such as food industries, home appliances and electronics, cars and motors. Second, the current research had focused on consequences of social media marketing such as brand awareness, however, other consumer brand relationships that have never been studied in Egyptian context should be examined such as brand involvement, attachment, defense, love, identification, loyalty, engagement, and image.

Third, the current research had focused on consequences of social media marketing (brand awareness), however, another marketing concepts related to customers such as trust, delight, purchase intention, and commitment should be studied. Forth, antecedents of social media marketing or what could enhance organizations' presence on social media should be examined too (factors which could influence organizations social media marketing efforts) such as customers' personality traits and browsing motives. Fifth, this study had focused on social media marketing consequences from customers' viewpoints, however, social media marketing financial consequences such as return on investment, return on equity, and earnings are suggested for future research. Sixth, this study has been limited on Facebook as one of the most famous social media, however other social media platforms differ in browsing and sharing styles, studying the effect of social media marketing executed on twitter, youtube, and Instagram is suggested.

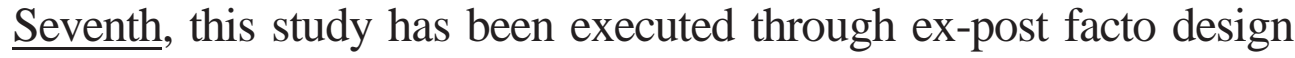
which is a quasi-experiment design which may affect the causality of the relationships among the research variables, therefore, other true experiment designs are recommended to be used for better causeeffect relationhips.

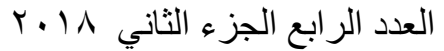

المجلد التاسع 
The role of Demographics and Psychographics in the relationship ......

Omnia Abdelazeem abdelhaleem Hilal

\section{References:}

Abeza, G. Z. (2012). An exploratory study of the opportunities and challenges of social media in meeting relationship marketing goals in sport organizations (Doctoral dissertation, University of New Brunswick, Faculty of Kinesiology).

Advertiser Perceptions (2012), Advertiser Intelligence Reports Wave 16: Digital Media Landscape, Advertiser Perceptions, New York, NY, available at:www.emar keter.com/Article.aspx? $\mathrm{R}=1008926$ (accessed 5 June). [Google Scholar]

Alalwan, A. A. (2018). Investigating the impact of social media advertising features on customer purchase intention. International Journal of Information Management, 42, 65-77.

Alkhas, A., 2011. An examination of Internet social media marketing in higher education institutions (Doctoral dissertation).

Aloch, (2017). Social media marketing and business growth of commercial (Doctoral dissertation, School of Business, University of Nairobi)

Amin, H., Qureshi, J. A., \&Chandio, S. (2017). Cultural, Ethical and Legal Considerations of Using Social Media Marketing in KarachiPakistan. Journal of Independent Studies \& Research: Management \& Social Sciences \& Economics, 15(2).

Assael, H. (2004). Consumer behavior: a strategic approach: Houghton Mifflin.

Atilgan, E., Aksoy, Ş., \& Akinci, S. (2005). Determinants of the brand equity: A verification approach in the beverage industry in Turkey. Marketing intelligence \& planning, 23(3), 237-248.

Barreda, A. A., Bilgihan, A., Nusair, K., \&Okumus, F. (2015). Generating brand awareness in online social networks. Computers in human behavior, 50, 600609.

Barwise, P., \& Meehan, S. (2010). The one thing you must get right when building a brand. Harvard business review, 88(12).

Bennett, S. (2013) 6 amazing social media statistics for brands and businesses [INFOGRAPHIC]. Retrieved from http://www.mediabistro.com/alltwitter /social media-facts b40978.

Best, D. (2011). Global: Most firms do not measure social media ROI - survey. Retrieved from http://www.just-food.com /news/most-firms-do-not-measuresocial-media-roi-survey_id116171.aspx

Bieda, J. C., \&Kassarjian, H. H. (1969). An overview of market segmentation. Marketing in a Changing Worlds, Chicago, AMA, 249-253.

Bonds-Raacke, J., \& Raacke, J. (2010). MySpace and Facebook: Identifying dimensions of uses and gratifications for friend networking sites. Individual

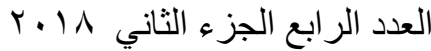

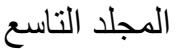


The role of Demographics and Psychographics in the relationship ......

Omnia Abdelazeem abdelhaleem Hilal

Differences Research, 8(1).

Botha, H. (2014). Considerations and implications of social media and the integration thereof in the sales and marketing process: A Pharmaceutical perspective (Doctoral dissertation, University of Pretoria).

Brockman, B. K. and R. M. Morgan: 2006, 'The Moderating Effect of Organizational Cohesiveness in Knowledge Use and New Product Development', Journal of the Academy of Marketing Science 34, 295-307.

Brown, T. A. (2014). Confirmatory factor analysis for applied research. Guilford Publications.

Bruhn, M., Schoenmueller, V., \& Schäfer, D. B. (2012). Are social media replacing traditional media in terms of brand equity creation? Management Research Review, 35(9), 770-790.

Brunsø, K., Verbeke, W., Ottar Olsen, S., \&Fruensgaard Jeppesen, L. (2009).

Motives, barriers and quality evaluation in fish consumption situations: Exploring and comparing heavy and light users in Spain and Belgium. British Food Journal, 111(7), 699-716.

Bulearca, M., \&Bulearca, S. (2010). Twitter: A viable marketing tool for SMEs? Global Business \& Management Research, 2(4), 296-309.

Bullas, J. (2013). 21 awesome social media facts, figures and statistics for 2013. Retrieved from http://www.jeffbullas.com /2013/05/06/21-awesome-socialmediafacts-figures-and-statistics-for-2013/.

Calder, B. J., Malthouse, E. C., \&Schaedel, U. (2009). An experimental study of the relationship between online awareness and advertising effectiveness. Journal of interactive marketing, 23(4), 321-331.

Chanthinok, K., Ussahawanitichakit, P., \& Jhundra-indra, P. (2015, July). Social media marketing strategy and marketing outcomes: A conceptual framework. In Allied Academies International Conference. Academy of Marketing Studies. Proceedings (Vol. 20, No. 2, p. 35). Jordan Whitney Enterprises, Inc.

Cheng, A. L., Kang, Y. K., Chen, Z., Tsao, C. J., Qin, S., Kim, J. S., ... \& Xu, J. (2009). Efficacy and safety of sorafenib in patients in the Asia-Pacific region with advanced hepatocellular carcinoma: a phase III randomised, doubleblind, placebo-controlled trial. The lancet oncology, 10(1), 25-34.

Chui, M., Manyika, J., Bughin, J., Dobbs, R., Roxburgh, C., Sarrazin, H., Sands, G., et al. (2012) The social economy: Unlocking value and productivity through social technologies. http://www.mckinsey.com /insights/high_tech_ telecoms_internet/the_social_economy, last accessed 6 July 2014.

Costa, T., Borges-Tiago, T., \& Tiago, F. (2018). Pharmaceutical Communication over Social Media Channels: 24/7 Management Challenges. In Digital Communication Management. IntechOpen. 
The role of Demographics and Psychographics in the relationship ......

Omnia Abdelazeem abdelhaleem Hilal

Edrees, Thabet Abderlrahaman (1996) measuring service quality using perception expectations gap scale: a study applied on medical services in Kuwait. The Arab Journal of Administrative Sciences. November, Issue 4, pp. 9-40.

Engel, J., Blackwell, R. and Miniard, P. (1990), Consumer Behavior, 6th ed., The Dryden Press, Chicago, IL.

Evans, D. (2010). Social media marketing: The next generation of business awareness. Sybex: Wiley Publishing.

Experian. (2013, April 16). Experian marketing services reveals 27 percent of time spent online is on social networking. Retrieved from http://press.experian.com/ United-States/Press-Release/experian-marketingservices-reveals-27-percent-of-timespent-online-is-on-socialnetworking.aspx.

Garnyte, M., \& de Ávila Pérez, A. (2009). Exploring Social Media Marketing. Aarhus School of Business, University of Aarhus.

Gazzar, N. E. (2013). The role of social media in the formation of public opinion towards Islamists: A content analysis. Journal of Arab \& Muslim Media Research, 6(1), 35-49.

Girard, T., Korgaonkar, P., \&Silverblatt, R. (2003). Relationship of type of product, shopping orientations, and demographics with preference for shopping on the Internet. Journal of Business and Psychology, 18(1), 101120.

Gironda, J. (2014). Tailored vs. invasive advertising: An empirical examination of antecedents and outcomes of consumers' attitudes toward personalized advertising. Florida Atlantic University.

Golijan, R., 2011. Just how many active Twitter users are there.

Gordon, A. (2017). Social Media Marketing Strategies in Nonprofit Professional Membership Organizations.

Grant Thornton LLP. (2010). Food for Thought. 3rd Annual Food and Beverage Industry forum. Retrieved

from http://www.gt.com/staticfiles/GTCom/CIP/Food\%20and \%20beverage/F\&B_Newsletter_FINAL.pdf

Guilford, J. P. (1961). Creative Thinking in Children at The Junior High School Levels.

Gummerus, J., Liljander, V., Weman, E., \&Pihlström, M. (2012). Customer awareness in a Facebook brand community. Management Research Review, 35(9), 857-877.

Hair, J. F., Black, W. C., Babin, B. J., \& Anderson, R. E. 2010. Multivariate data analysis, (7th edn) Upper addle River, NJ: Prentice Hall. 
The role of Demographics and Psychographics in the relationship ......

Omnia Abdelazeem abdelhaleem Hilal

Hames, M. (2009, November 17). Facebook page marketing: The pros and cons. Retrieved from http://sharemarketing.wordpress.com/2009/11/17/ facebookpage-marketing-the-pros-and-cons/.

Hawes, D. K. (1978). Empirically profiling four recreational vehicle market segments. Journal of Travel Research, 16(4), 13-20.

Himberg, C. (1996). Video technology and the subjective norm, perceived behavioral control, and attitude towards physical activity of middle school students: Does P.E.TV make a difference? 1-99.

Homburg, C., \&Giering, A. (2001). Personal characteristics as moderators of the relationship between customer satisfaction and loyalty-an empirical analysis. Psychology \& Marketing, 18(1), 43-66.

Hoy, M. G., \& Milne, G. (2010). Gender differences in privacy-related measures for young adult Facebook users. Journal of Interactive Advertising, 10(2), $28-45$.

Hustad, T. P., \&Pessemier, E. A. (1971). Segmenting consumer markets with activity and attitude measures. Institute for Research in the Behavioral, Economic, and Management Sciences, Herman C. Krannert Graduate School of Industrial Administration, Purdue University.

Hutter, K., Hautz, J., Dennhardt, S., \&Füller, J. (2013). The impact of user interactions in social media on brand awareness and purchase intention: the case of MINI on Facebook. Journal of Product \& Brand Management, 22(5/6), 342-351.

Ioakimidis, M. (2010). Online marketing of professional sports clubs: Engaging fans on a new playing field. International journal of sports marketing and sponsorship, 11(4), 2-13.

Kaplan, A.M. and Haenlein, M., 2010. Users of the world, unite! The challenges and opportunities of Social Media. Business horizons, 53(1), pp.59-68.

Karikari, S., Osei-Frimpong, K., \& Owusu-Frimpong, N. (2017). Evaluating individual level antecedents and consequences of social media use in Ghana. Technological Forecasting and Social Change, 123, 68-79.

Karimi, S., \& Naghibi, H. S. (2015). Social media marketing (SMM) strategies for small to medium enterprises (SMEs). International Journal of Information, Business and Management, 7(4), 86.

Keller, K. L. (1993) "Conceptualizing, Measuring, and Managing CustomerBased Brand Equity.” The Journal of Marketing 57 (1): 1-22.

Keller, K. L. (2009). Building strong brands in a modern marketing communications environment. Journal of marketing communications, 15(23), 139-155.

Keller, K. L. (2013). Strategic Brand Management: Building, measuring, and 
The role of Demographics and Psychographics in the relationship ......

Omnia Abdelazeem abdelhaleem Hilal

managing brand equity (4th ed.). Upper Saddle River: Pearson Education.

Khan, I., \& Rahman, Z. (2016). E-tail brand experience's influence on e-brand trust and e-brand loyalty: the moderating role of gender. International Journal of Retail \& Distribution Management, 44(6), 588-606.

Kim, A. J., \& Ko, E. (2012). Do social media marketing activities enhance customer equity? An empirical study of luxury fashion brand. Journal of Business Research, 65(10), 1480-1486.

Korgaonkar, P. K., \& Wolin, L. D. (1999). A multivariate analysis of web usage. Journal of Advertising Research, 39, 53-68.

Koufaris, M. (2002). Applying the technology acceptance model and flow theory to online consumer behavior. Information Systems Research, 13(2), 205-223.

Krejcie, R. V., \& Morgan, D. W. (1970). Determining sample size for research activities. Educational and psychological measurement, 30(3), 607-610.

LaPointe, P. (2012). Measuring Facebook's impact on marketing: The proverbial hits the fan. Journal of Advertising Research, 52(3), 286-287.

Lee, C., Kim, J., \& Chan-Olmsted, S. M. (2011). Branded product information search on the Web: The role of brand trust and credibility of online information sources. Journal of Marketing Communications, 17(5), 355-374.

Liu, D. (2012). Benchmarking Data Reveals Pharmaceutical Industry Not Connecting Social Media Data with Marketing Strategies. IBM Global Business Services, 6.

Lorenzo-Romero, C., Constantinides, E., \&Alarcón-del-Amo, M. D. C. (2013). Web aesthetics effects on user decisions: impact of exposure length on website quality perceptions and buying intentions. Journal of internet commerce, 12(1), 76-105.

Mägi, A. W. (2003). Share of wallet in retailing: the effects of customer satisfaction, loyalty cards and shopper characteristics. Journal of retailing, 79(2), 97-106.

Malhotra, A., Malhotra, C. K., \& See, A. (2013). How to create brand awareness on Facebook. MIT Sloan Management Review, 54(2), 18-20.

Marshall, G. W., Moncrief, W. C., Rudd, J. M., \& Lee, N. (2012). Revolution in sales: The impact of social media and related technology on the selling environment. Journal of Personal Selling and Sales Management, XXXII (3), 349-363.

Marzouk, W. G. (2016). Usage and Effectiveness of Social Media Marketing in Egypt: An Organization Perspective.Jordan Journal of Business Administration, 12(1).

Michaelidou, N., Siamagka, N. T., \&Christodoulides, G. (2011). Usage, barriers and measurement of social media marketing: An exploratory investigation of

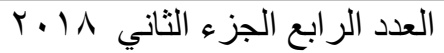

المجلد التاسع 
The role of Demographics and Psychographics in the relationship ......

Omnia Abdelazeem abdelhaleem Hilal

small and medium B2B brands. Industrial marketing management, 40(7), 1153-1159.

Mitchell, A. (1983). The nine American lifestyles. New York, NY: Warner.

Muñiz Jr, A. M., \& Schau, H. J. (2011). How to inspire value-laden collaborative consumer-generated content. Business Horizons, 54(3), 209-217.

Muntinga, D. G., Moorman, M., \& Smit, E. G. (2011). Introducing COBRAs: Exploring motivations for brand-related social media use. International Journal of advertising, 30(1), 13-46.

Myrland, Ø., Trondsen, T., Johnston, R. S., \& Lund, E. (2000). Determinants of seafood consumption in Norway: lifestyle, revealed preferences, and barriers to consumption. Food quality and Preference, 11(3), 169-188.

Naylor, R. W., Lamberton, C. P., \& West, P. M. (2012). Beyond the "like" button: The impact of mere virtual presence on brand evaluations and purchase intentions in social media settings. Journal of Marketing, 76(6), 105-120.

Ntobaki, P. P. (2018). The influence of social media marketing on Durban consumers' choice of brands (Doctoral dissertation).

Olsen, S. O., J. Scholderer, K. Brunso, and W. Verbeke. 2007. "Exploring the Relationship Between Convenience and Fish Consumption: A Cross-Cultural Study." Appetite 49:84-91.

Ouoba, S.E.M., 2011. Investigating the Effectiveness of Social Media Sites in Shaping the Opinion of the Audience of Companies in the Food and Beverage Industry: Facebook and Twitter (Doctoral dissertation, Hawaii Pacific University).

Peslak, A. , Ceccucci, W., \& Sendall, P. (2011). An empirical study of social networking behavior using theory of reasoned action.EDSIG, 4(1807), 1-13.

Pieniak, Z., Verbeke, W., Scholderer, J., Brunsø, K., \& Ottar Olsen, S. (2008). Impact of consumers' health beliefs, health involvement and risk perception on fish consumption: A study in five European countries. British Food Journal, 110(9), 898-915.

Piskorski, M. J. (2011). Social strategies that work. Harvard Business Review, 89(11), 116-122.

Pring, Cara (2012, January 11). 100 Social media statistics for 2012. The Social Skinny. Retrieved from http://thesocialskinny.com.

Scott, D. (2007). The new rules of marketing and PR. Hoboken, NJ: John Wiley $\&$ Sons.

Sekaran, U., \& Bougie, R. (2016). Research methods for business: A skill building approach. John Wiley \& Sons.

Sheth, S. N. (2013). Social Media, a New Revolution in the Field of Marketing:

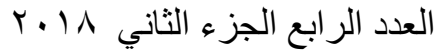

المجلد التاسع 
The role of Demographics and Psychographics in the relationship ......

Omnia Abdelazeem abdelhaleem Hilal

The Effect of Information Sharing, Peer Pressure, Entertainment and

Emotional Connection on the Attitude towards the Brand and in Turn the

Purchase Intention from the Brand.

Smith, C. (2013, July 19). 10 social media statistics that should shape your social

strategy. Retrieved from http://www.businessinsider.com/strategic-socialmediastatistics-2013-7.

Smock, A.D., Nicole, B.E., Lampe, C., \& Wohn, D.Y. (2011). Facebook a toolkit: A uses and gratification approach to unbundling feature use. Computers in Human Behavior, 27, 2322-2329.

Soh, H., Reid, L. N., \& King, K. W. (2009). Measuring trust in advertising. Journal of Advertising, 38(2), 83-104.

Solangaarachchi, D. I. K., Marasinghe, M. P. L. R., Abeygunasekera, C. M., Hewage, S. N., \& Thulani, U. B. (2016). Use of Library and Internet Facilities for Seeking Information among Medical Students at Faculty of Medicine, University of Kelaniya.

Somali, H. (2018). Assimilation of social media marketing in Saudi large companies: antecedents and consequences (Doctoral dissertation, Sheffield Hallam University).

Stephen, A.T., 2016. The role of digital and social media marketing in consumer behavior. Current Opinion in Psychology, 10, pp.17-21.

Straughan, R. D., \& Roberts, J. A. (1999). Environmental segmentation alternatives: a look at green consumer behavior in the new millennium. Journal of ConsumerMarketing, 16(6), 558-575.

Sun, T., Horn, M., \& Merritt, D. (2004). Values and lifestyles of individualists and collectivists: a study on Chinese, Japanese, British and US consumers. Journal of consumer marketing, 21(5), 318-331.

Swani, K., Milne, G. R., Cromer, C., \& Brown, B. P. (2013). Fortune 500 companies' use of twitter communications: A comparison between product and service tweets. International Journal of Integrated Marketing Communications, 5(2), 47-56.

Swinyard, W.R. \& Smith, S.M. (2003). Why people (don't) shop online: A lifestyle study of the internet consumer. Psychology \& Marketing, 20(7), 567-587.

Thoring, A. (2011). Corporate tweeting: Analyzing the use of Twitter as a marketing tool by UK trade publishers. Publishing Research Quarterly, 27(2), 141-158.

Traphagen, M., 2015. Why awareness does matter as a social media metric. Retrieved on Apr, 3, 2015.

Tsiros, M., Mittal, V. \& Ross, W. (2004), The role of attributions in customer

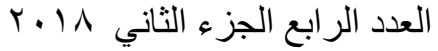
المجلد التاسع 
The role of Demographics and Psychographics in the relationship ......

Omnia Abdelazeem abdelhaleem Hilal

satisfaction: a re-examination, Journal of Consumer Research, 31(3), 476-83

Tsitsi Chikandiwa, S., Contogiannis, E., \&Jembere, E. (2013). The adoption of social media marketing in South African banks. European Business Review, 25(4), 365-381.

Vale, L., \& Fernandes, T. (2018). Social media and sports: driving fan awareness with football clubs on Facebook. Journal of Strategic Marketing, 26(1), 3755.

Vance, Ashlee (2012), "Facebook: The Making of 1 Billion Users." Bloomberg Businessweek, October 10 (available at: http://www.businessweek.com/articles/2012-10- 4/facebook-the-making-of1-billion-users)

Wang, X., Yu, C., \& Wei, Y. (2012). Social media peer communication and impacts on purchase intentions: A consumer socialization framework. Journal of interactive marketing, 26(4), 198-208.

Wells, W. D., Tigert, D. J., \& Activities, Interests, and opinions. (1971). Opinions. Journal of advertising research, 11(4), 27-35.

Williams, J. and Chinn, S.J., 2010. Meeting relationship-marketing goals through social media: A conceptual model for sport marketers. International Journal of Sport Communication, 3(4), pp.422-437.

Wulf, K. D., Odekerken-Schröder, G., \&Iacobucci, D. (2001). Investments in consumer relationships: A cross-country and cross-industry exploration. Journal of marketing, 65(4), 33-50.

Yadav, M., \& Rahman, Z. (2017). Measuring consumer perception of social media marketing activities in e-commerce industry: Scale development \& validation. Telematics and Informatics, 34(7), 1294-1307.

Yoo, B., Donthu, N., \& Lee, S. (2000). An examination of selected marketing mix elements and brand equity. Journal of the academy of marketing science, 28(2), 195-211.

$\mathrm{Yu}, \mathrm{C}$. S. (2011). Construction and validation of an e-lifestyle instrument. Internet Research, 21(3), 214-235.

Zaglia, M. E., 2013. "Brand Communities Embedded in Social Networks." Journal of Business Research 66: 216-223. 